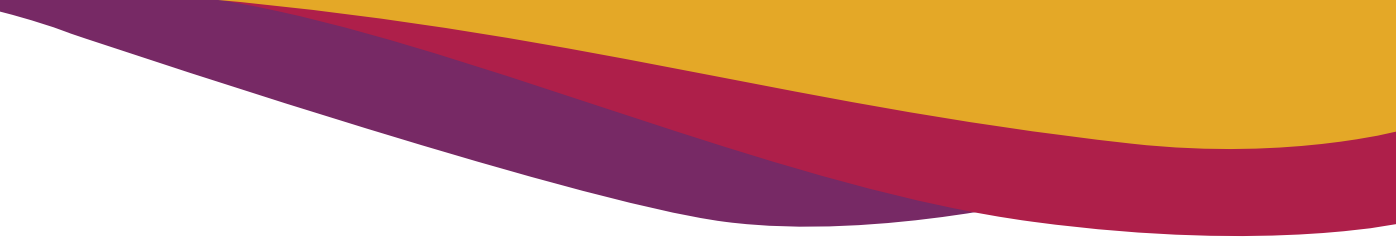

TRADUÇÃO

\title{
Performatividade queer da natureza ${ }^{1}$
}

Karen Barad ${ }^{2}$

Resumo: Neste artigo, Karen Barad levanta a possibilidade de queeridade em uma das mais ubíquas criaturas - os átomos. Com suas qualidades quânticas cotidianas, essas criaturas "ultraqueers", em seus modos de existência radicalmente desconstrutivos, queerizam a própria queeridade. Dado que o queer é um questionamento radical da identidade e dos binários, incluindo o binário natureza/cultura, este ensaio pretende demonstrar que todo tipo de impossibilidade é, de fato, possível, incluindo a queeridade da causalidade, da matéria, do espaço e do tempo. O que aconteceria, pergunta Barad, se a queeridade fosse entendida não como residente nos interstícios de natureza/cultura per se, mas na própria natureza da espaçotempomaterialização? Este ensaio também considera questões de ética e justiça e, particularmente, examina os modos como o moralismo insiste em reativar a divisão natureza/cultura. Barad argumenta que o moralismo se alimenta do excepcionalismo humano, em especial da superioridade humana, causa danos tanto a humanos quanto a não humanos, é um portador hereditário do ódio genocida e negligencia as ecologias da diversidade necessárias por florescer.

Palavras-chave: performatividade; natureza; emaranhamentos.

Escorre pelo solo do Texas um time de bilhões de amebas (YOON, 2009)² é a

manchete de uma notícia permeada por imaginários poderosos que coletivamente exalam um cheiro de temor, para não dizer levemente moralista ${ }^{4}$. O corpo da notícia é repleto de indícios dos tipos de fenômenos que estão em discussão neste ensaio: preocupações em

\footnotetext{
${ }^{1}$ A versão autorizada deste texto foi publicada em BARAD, Karen. Nature's Queer Performativity. Women, Gender \& Research, n. 1-2, p. 25-52, 2012. Agradecemos a autora por sua autorização para publicar esta versão em português. Tradução de Jorge Felipe Marçal. Email: jorgefelipemgomes@gmail.com. Revisão e notas por Thiago Ranniery. Email: t.ranniery@gmail.com

2. Universidade da Califórnia, Estados Unidos. Email: kbarad@ucsc.edu.

${ }^{3}$ Nota da revisão: em virtude do uso realizada pela autora da reportagem na sessão, nós optamos por marcar em itálico os trechos retirados da matéria a fim de diferenciar de outras as citações.

${ }^{4}$ Uma versão previamente não autorizada deste texto foi publicada na revista Qui Parle. Sou grata a Hilda Rømer Christensen e aos editores da Women, Gender \& Research por me conferirem a oportunidade de trazer à luz a versão autorizada do ensaio.
}

Vol. 03, N. 11, Jul. - Set., 2020 - http://periodicoscientificos.ufmt.br/ojs/index.php/rebeh/index 
relação a fundamentos, estabilidade e instabilidade, reconfigurações e mudanças de forma, agência não humana, comportamentos queers de criaturas, medo e moralismo, e natureza/cultura, micro/macro, cruzamentos de fronteiras temporais e espaciais.

Cientistas encontraram o vasto e pegajoso império de 12 quilômetros de extensão, que consiste em indivíduos unicelulares geneticamente idênticos, entranhandose pela lama de um pasto nos arredores de Houston ${ }^{5}$. A mistura de moralidade, política e fluidos corporais - a agregação de terrores noturnos de um movimento subterrâneo coletivo e das repulsões da carne - formam um coquetel tentador. A linguagem descritiva é pontual e evocativa - vasto e pegajoso império [...] entranhando-se pela lama - e as imagens, sustentadas em suspensão coloidal ali mesmo na superfície, estão repletas de odores mofados de medo. Não é preciso ir muito além da superfície para testemunhar a fusão de ansiedades políticas e curiosidade científica em um organismo multicelular mais complexo:

Embora amebas possam parecer pouco capazes de coordenar interações umas com as outras por muito mais que distâncias microscópicas, a descoberta da tão grande colônia de clones", disse [Kevin Foster, um biólogo evolucionista de Harvard], "suscita a possibilidade de que células possam evoluir a ponto de se organizarem em escalas espaciais muito maiores".

[...] Na verdade, assim como a colonia de amebas sociais, as amebas gigantes podem estar em todo lugar sob nossos pés sem que ninguém se dê conta disso.

"Eu costumava brincar", disse o Dr. Schliwa, "que talvez exista um organismo gigante no solo espalhando-se pelo continente inteiro e que, onde quer que você cave, você possa pegar um pedaço dele”. Então, onde será encontrada a próxima ameba gigante? Dr. Schliwa aponta que a descoberta da "ameba das amebas" foi feita nos anos 1940 por uma pesquisadora chamada Ruth N. Nauss. Ela descobriu a espécie no parque da cidade de Nova York.

Descortinando o funcionamento de sua própria dramatização, a autora do artigo do The New York Times faz emergir imaginários subterrâneos ao externar o fantasma velado do clássico de terror A bolha assassina, de 1958: um filme lançado no auge da Guerra Fria frente à assustadora ameaça do comunismo. O tema do anticomunismo perpassa o artigo e se infiltra na (apresentação da) descrição científica: Uma contradição apenas aparente, as amebas sociais são capazes de se engajar em grupos organizados e

\footnotetext{
${ }^{5}$ Todas as citações nesta seção são do artigo do New York Times, exceto onde for indicado.
}

Vol. 03, N. 11, Jul. - Set., 2020 - http://periodicoscientificos.ufmt.br/ojs/index.php/rebeh/index 
se comportar cooperativamente, algumas até cometendo suicídio para auxiliar as companheiras a se reproduzir. O sacrifício do indivíduo em nome do bem coletivo cabe como uma luva no tema do medo vermelho e "suicídio" - um termo interessante, dado que implica intencionalidade e a metafísica do individualismo - é, de fato, um modo comum dos cientistas e jornalistas da ciência se referirem ao destino das amebas “individuais" no processo de agregação. Entretanto, essa não é uma leitura muito peculiar do comportamento de organismos que inicialmente receberam o nome do deus Proteus Proteus animalcule -, conhecido por suas mudanças de forma? Uma massa amorfa, cujas partes podem se repartir e gerar vida própria, um organismo que se modifica de um grupo aparentemente desordenado de células individuais geneticamente idênticas para tornar-se uma "lesma" agregada com um sistema imune e outras funcionalidades características de espécies pluricelulares com diferentes papéis cumpridos por unidades celulares idênticas ${ }^{6}$. Como o professor John Tyler Bonner, que passou sua vida estudando fungos mucilaginosos, afirma, tal grupo de seres vivos - dos quais amebas sociais ou fungos mucilaginosos celulares (Dictyosteliida) fazem parte - "não são mais do que uma bolsa de amebas cobertas por uma fina camada viscosa, porém com a capacidade de ter comportamentos iguais aos de animais que possuem músculos e gânglios nervosos (em palavras rudimentares, cérebros mais simples)"”.

O que é ou o que não é um “indivíduo" não é uma questão simples e definitiva. Esse parece ser um ponto científico crucial: a questão da natureza da identidade é plenamente visível aqui - e isto é verdadeiramente espetacular de um ponto de vista científico. Não surpreendentemente as amebas sociais são tomadas como um organismo modelo na biologia molecular e na genética para estudar a comunicação e a diferenciação celular. Amebas sociais queerizam a natureza da identidade, colocando em questão o binário indivíduo/grupo. Na verdade, quando o assunto é queerizar identidades, amebas sociais expressam múltiplas indeterminações e bagunçam as tentativas científicas contemporâneas para resolver sua taxonomia e sua identidade específica, desafiando não

\footnotetext{
${ }^{6}$ É tão interessante que "Em resposta à sinalização de estresse do AMPc (AMP cíclico, molécula orgânica de sinalização celular), até cem mil amebas se reúnem. Elas primeiro formam uma torre, que acaba caindo em uma bolha oblonga com cerca de dois milímetros de comprimento. As amebas idênticas dentro deste pseudoplasmódio começam a se diferenciar e a assumir papéis especializados" (OTTE, 2007. s/p). Ver nota de rodapé 8.

${ }^{7}$ Citação atribuída a John Tyler Bonner, autor do artigo sobre Slime Molds na Wikipedia.
}

Vol. 03, N. 11, Jul. - Set., 2020 - http://periodicoscientificos.ufmt.br/ojs/index.php/rebeh/index 
só sua classificação em um filo, mas também em um reino ${ }^{8}$. Apesar disso, o viés retórico favorece a narrativa do sacrifício individual pelo bem comum. É de se esperar que a leitora não precise de muito esforço para desenterrar o tom político e moralista.

Enquanto a jornalista está claramente se divertindo com sua matéria, a resposta afetiva estimulada pela conjuração jocosa desse espectro não é puramente nostálgica, uma vez que a Bolha Assassina - uma criatura proteica, viscosa e irrefreável que consome tudo em seu caminho, uma literalização particularmente vívida do medo de ser consumido pelo Outro na forma de pânico xenofóbico em resposta a elementos externos - não morreu com o macartismo, mas resistiu durante os anos da Guerra do Vietnã e mesmo durante os anos Reagan. O anticomunismo raivoso não é a única forma que esse medo assume. No curso da história, passou por mutações e multiplicou seus modos de incorporar outros medos sociais, estabelecendo as condições para a reatividade e a disseminação do ódio e do desprezo pelo Outro. Por exemplo, a Bolha Assassina tornou-se viral nos anos recentes, produzindo uma combinação de pânico e negligência em vez de compaixão e responsividade durante crises de saúde pública, tais como a epidemia de AIDS, a epidemia da doença da vaca louca e a epidemia de gripe aviária, o que resultou, respectivamente, no pronto sacrifício de humanos (particularmente de homens gays, usuários de drogas intravenosas e adultos e crianças vivendo na África Subsaariana), de mamíferos não humanos (particularmente de vacas) e de aves (particularmente galinhas). A incitação sistêmica do medo e do ódio é também evidente na disseminação da doença racial, religiosa e étnica, como nos casos de islamofobia nos EUA e na Europa, no reaparecimento de seitas virulentas antissemitas na Europa meros cinquenta anos após o Holocausto e na última leva de legislações anti-imigração descaradamente racistas no Arizona, para ficar com apenas alguns exemplos. Sob diversas formas, a Bolha Assassina está plenamente viva no cenário político contemporâneo.

\footnotetext{
${ }^{8}$ Descoberta em uma floresta da Carolina do Norte em 1935, a espécie Dictyostelium discoideum foi classificada primeiro no grupo de "fungos primitivos" (classificação, hoje, em desuso) e depois nos reinos Protoctista, Fungi e Tubulomitochondrae. Nos anos 1990, a maioria dos cientistas aceitou a classificação atual. Amoebozoa são, agora, considerados como formando de um clado separado, sendo mais relacionados a fungos e animais do que a plantas (entrada na Wikipedia para Dictyostelid). Agradeço Fern Feldman por compartilhar meu interesse nas indeterminações das amebas sociais e por apontar os desvios na classificação biológica dessas criaturas.
}

Vol. 03, N. 11, Jul. - Set., 2020 - http://periodicoscientificos.ufmt.br/ojs/index.php/rebeh/index 
Ao caminhar na lama pegajosa da moralidade, da política e dos fluidos corporais, não há nada de inocente no estímulo burlesco da resposta pelo medo. Um agregado de medo e pavor trabalha sob a superfície e quando as condições são favoráveis, ele escorre a céu aberto. Medo e moralismo fazem uma mistura cáustica.

Na verdade, quando falamos de amebas sociais, não é necessário procurar muito para encontrar todo tipo de retórica moralista. Moralidade amébica", título do artigo, é uma expressão que trai qualquer sutileza e não está nem um pouco fora da órbita do jornalismo da ciência em seu uso de descritores morais como "nobre", "trapaceiro", "parasitas", “cooperando com estranhos", "auto-sacrifício" para descrever comportamentos amébicos. Isso explica também que amebas estejam sendo usadas em estudos laboratoriais de altruísmo, como se fosse o caminho de investigação mais natural, sem reconhecer a circularidade em funcionamento ${ }^{9}$. Chega-se a ponderar: a Natureza é um ator moral exemplar ou uma ativista comunista (ou, que os céus nos perdoem, os dois)? Seria um grave erro concluir que estou, aqui, enumerando os pecados de antropomorfizar. Em vez disso, estou profundamente interessada na "antropomorfização" como uma intervenção para perturbar as escalas tóxicas e rígidas do antropocentrismo, nas quais o humano em sua excepcional forma de existência concentra todas as "boas" qualidades, tais como agência, intencionalidade, racionalidade, sentimento, dor, empatia, linguagem, consciência, imaginação e muito mais. Em outras palavras, meu interesse está em problematizar os pressupostos que sustentam o anthropos, incluindo a separação entre o "humano" e seus outros. O que sugiro não é um antropomorfismo estratégico per se, mas usar o momento antropomórfico para levantar questões. Não para reiterar os hábitos de projeção, mas para fraturar as suposições do anthropos do antropocentrismo, abrindo, assim, um caminho para resposta - isto é, realizando um convite ao outro para responder ao colocar-se em risco, fazendo o trabalho necessário para tornar possível uma resposta e

\footnotetext{
9 Por Carol Otte, postado em 9 de outubro de 2007. Disponível em: http://www.damninteresting.com/amoebic-morality. Acesso em: 5 jul. 2010. Este é um artigo interessante, uma compilação bem escrita dos diferentes resultados de pesquisa sobre amebas sociais. Os usos da linguagem ou da moralidade por Otte não são simples sensacionalismo para atrair leitores. Em vez disso, questões de moralidade circulam com grande regularidade na literatura científica sobre amebas sociais, $o$ que é um fenômeno bastante peculiar.
}

Vol. 03, N. 11, Jul. - Set., 2020 - http://periodicoscientificos.ufmt.br/ojs/index.php/rebeh/index 
removendo, portanto, (parte do) peso das camadas incrustadas de impossibilidades não humanas (ou, pelo menos, abrindo orifícios que permitam alguma ventilação) ${ }^{10}$.

Dessa forma, eu sugiro que a dificuldade com a qual nos defrontamos não é a atribuição de virtudes morais a não humanos por si só, mas é tributária do poderoso e penetrante moralismo, particularmente quando direcionado à divisão natureza/cultura ${ }^{11}$. Dado que o moralismo pinta humanos como os únicos agentes morais em cena, a divisão natureza/cultura é não apenas uma fronteira arcaica, mas o próprio ar que se respira. Não espanta, deste modo, que o moralismo veja a si mesmo como destinado a proteger essa sagrada fronteira com ferocidade. Existe, no entanto, um tipo de doce justiça na ironia de que, ao passo que o medo e o moralismo são lançados em um estado febril cujo objetivo é salvaguardar a divisão natureza/cultura, uma brecha compulsiva em tal divisão insiste inevitavelmente em aparecer, como um tique incontrolável.

Considere o seguinte exemplo: a (i)lógica da noção de "crimes contra a natureza", um termo legal que faz referência a "atos sexuais contrários à ordem da natureza", incluindo todos os "atos de caráter bestial pelos quais se busca gratificação de desejos sexuais degradados e pervertidos" $" 12$. Mais comumente, a expressão refere-se à "sodomia" e, particularmente, a atos sexuais entre pessoas do mesmo sexo. Ainda hoje, penas criminais por cometer atos sexuais "contra a natureza" chegam à prisão perpétua (ver, por exemplo, os estatutos do estado de Idaho) ou mesmo à pena de morte ${ }^{13}$.

A conjunção perversa de natureza, sexualidade e moralidade está vividamente ilustrada na seguinte declaração: "a sodomia é condenada porque a base racional de toda

\footnotetext{
${ }^{10}$ Por exemplo, se a noção de "amebas sociais" como um oxímoro ou paradoxo for verdadeira, isto é, se existe uma crença operativa de que organismos unicelulares são simplesmente primitivos demais para engajar-se em relações sociais ou em qualquer forma de comportamento cooperativo (especialmente em grandes distâncias), colocar para escanteio a proibição de pensar em socialidade e agência como capacidades não humanas certamente é um passo importante para desfazer alguns dos efeitos sedimentares do excepcionalismo humano.

${ }^{11}$ Seguramente, a própria possibilidade do não humano moral abre uma ponderação, uma queerização, da moralidade de modo que ela não seja fundada na divisão natureza/cultura, mas que a coloque em questão. Com essa reorientação, "moralidade amébica" não constitui mais um movimento colonialista para cimentar secretamente os seres humanos na equação, estabelecendo o não-humano como recurso epistemológico, transformando tudo em uma questão do que o Outro pode nos ensinar, ou mesmo sobre em nome de quem 'nós' devemos falar como substituto da capacidade de resposta, ou seja, possibilitar que o outro responda. 12 Do código legal do estado da Carolina do Norte. Disponível em: http://www.ncgala.org/guide/guidcan.htm. Nota da revisão: sem data de acesso no original.

${ }^{13}$ Disponível em: http://www.everything2.com/index.pl?node id=1009724. Nota da revisão: sem data de acesso no original.
}

Vol. 03, N. 11, Jul. - Set., 2020 - http://periodicoscientificos.ufmt.br/ojs/index.php/rebeh/index 
moralidade é a natureza e a sodomia é contra a natureza”. Essa declaração, feita por Harry V. Jaffa, Professor Pesquisador da Cátedra Henry Salvatori de Filosofia Política na Claremont McKenna College e da Claremont Graduate School, foi retirada de uma resposta em oposição ao editorial publicado pelo The Los Angeles Times em 14 de janeiro de 1989. Um artigo de opinião online intitulado Homossexualidade e Lei da Natureza, publicado no website do ultradireitista The Claremont Institute, no sul da Califórnia, cita a resposta de Jaffa e finaliza o pensamento:

considerar 'a originária distinção entre macho e fêmea' arbitrária, [Jaffa] continua, 'é considerar todas as distinções nas quais toda a moralidade se sustenta - por exemplo, aquela que condena a escravização e o genocídio arbitrárias. Implica que somos livres para escolher se deve haver limitações objetivas para a ação humana, se deve haver padrões objetivos de certo ou errado' ${ }^{14}$.

Logo, de acordo com Jaffa, se a homossexualidade não for criminalizada, a base da moralidade cai por terra: a ilegalidade da homossexualidade é seu próprio fundamento. Essa (i)lógica é coerente com o fato perverso de que o crime mais hediondo contra a natureza, ao menos à luz de diferentes culturas, não é o assassinato em massa de não humanos ou daqueles denominados como humanos Outros, "menos-que-humanos", mas "atos sexuais não naturais", como atos sexuais não reprodutivos, especialmente a sodomia. Em outras palavras, "atos homossexuais".

O moralismo, que se alimenta do excepcionalismo humano e, particularmente, da superioridade humana (sem dúvidas, ser agente moral é uma forma na qual os humanos são ditos melhores do que as bestas), sustenta um injunção moral específica contra comportamentos humanos "não naturais". Há um preço a pagar por ir contra os "caminhos da natureza" e suas leis. Porém, se o crime é contra a Natureza em si - a Natureza como um todo, isto é, se o ato é tão notório a ponto de ir "contra tudo que é natural" -, o crime deve ser cometido por alguém de fora da Natureza, presumidamente um agente humano, um sábio de seus pecados. Agora, se o ato é contra a Natureza, e o autor não é da Natureza, mas de fora dela, então todos os atos, cometidos por tal ator, estão "em desacordo ou indeterminados pela Natureza; são "contra a natureza” - isto é, são “não naturais”, por

\footnotetext{
${ }^{14}$ Disponível em:

https://famguardian.org/Subjects/SexualImmorality/Homosexuality/HomoAndNaturalLaw.htm. Nota da revisão: sem data de acesso no original.
}

Vol. 03, N. 11, Jul. - Set., 2020 - http://periodicoscientificos.ufmt.br/ojs/index.php/rebeh/index 
definição ${ }^{15}$. Ao mesmo tempo, se a injunção moral é contra comportamentos humanos

"não naturais", incluindo agir como uma besta, isso quer dizer que se está agindo como a

Natureza - performando atos "naturais". Por essa razão, a (i)lógica em funcionamento tropeça na própria divisão - na divisão natureza/cultura - que pretende assegurar. Na verdade, é a lei em si - denominando alguns atos humanos como bestiais em sua natureza - que perturba a divisão sagrada, abrindo a possibilidade de humanos se engajarem em atos não humanos ${ }^{16}$. Portanto, é a própria lei que viola sua injunção, penetrando forçosamente a divisão natureza/cultura e cometendo a violação.

Outrossim, o discurso sobre "crimes contra a natureza" toma desde já liberdade ao confiar que a Natureza é ela mesma uma boa cristã, ou pelo menos transita sobre um tipo de pureza da qual o humano foi excluído desde a queda do Éden. Porém, e se a natureza em si for uma comuna, uma pervertida ou uma bicha estranha? Abrindo os

15 Do dicionário online. Disponível em: http://www.vocabulary.com/definition/unnatural. A indeterminação do significado de "natural" e "não natural" produz instabilidades interessantes. Nota da revisão: sem data acesso no original.

${ }^{16}$ Se alguém entende a lei como guardiã contra humanos que parodiam animais, não engajados de fato em "atos bestiais" propriamente, mas engajados em atos de mímica, isto é, em agir como se fosse um animal (não humano), um humano em pele de ovelha, por assim dizer, logo é a lei que propiciaria a humanos engajar-se numa forma ovina de cross-dressing ao marcar certos atos humanos como uma forma de drag que cruza a divisão natureza/cultura. $O$ tom jocoso na minha resposta a essa afirmação é intencional, já que o uso malicioso de tais relações de equivalência depende de que modo o "como se" é jogado. O uso de tais relações de equivalência através das fronteiras entre espécies nas quais o moralismo transita não pretende uma coisa tão "inocente" quanto um "como se". Certamente, segundo aponta Hugh Raffles (2010, p. 142), a afirmação de Himmler de que o "antissemitismo é exatamente o mesmo que despiolhamento" não é "mera" sugestão de que o "antissemitismo seja (...) 'como se' fosse despiolhamento, nem meramente uma forma de despiolhamento. É exatamente o mesmo que despiolhamento". O discurso propositalmente inflamado não é "meramente" de que judeus ajam como piolhos. O que está sendo propagado por Himmler é uma relação de equivalência: judeus são piolhos. Raffles $(2010$, p. 145) continua apontando que "embora os nazistas tenham imposto as fronteiras com uma ferocidade sem precedentes, eles não iniciaram a expulsão dos judeus do reino da humanidade. No início da França moderna, por exemplo, 'já que o coito com uma judia é exatamente o mesmo que se um homem copulasse com um cachorro', cristãos que tinham relações heterossexuais com judeus poderiam ser penalizados pelo crime capital de sodomia e queimados vivos com seus parceiros - 'tais pessoas aos olhos da lei e de nossa fé sagrada não se diferenciam em nada de bestas' (que também eram sujeitos a julgamento e execução). Em menor escala, a identificação alemã persistente de judeus com cachorros (vira-latas) e, vez ou outra, com porcos se estende até a época nazista. Mais destrutiva - e mais incisiva - era a associação de judeus com a figura sombria dos parasitas, uma figura que infesta o corpo individual, a população e, certamente, o corpo político, que o faz de maneiras tanto óbvias quanto inesperadas, e que convida a intervenções e a controles inovadores". Por essa razão, na próxima seção do ensaio, enfatizo a necessidade de romper radicalmente o cálculo de extermínio e matabilidade (a imoralidade de fazer matável). Se essa aritmética assassina é deixada inabalável, ao tentar negar a equivalência, defendendo apenas um lado da equação e desdenhando do outro, por exemplo, ela virá atormentar e ferir todo tipo de ser, humano e não humano. Como significamos o Outro importa. É importante estar claro que as relações de equivalência deste tipo não perturbam a divisão natureza/cultura - antes, alimentam-se dela.

Vol. 03, N. 11, Jul. - Set., 2020 - http://periodicoscientificos.ufmt.br/ojs/index.php/rebeh/index 
trabalhos com a famosa citação do biólogo evolucionista J. B. S. Haldane, "o universo é não só mais aberrante do que supomos, é mais aberrante do que podemos supor”, Bruce Bagemihl (2000, p. 9) escreve que o mundo está "repleto de criaturas homossexuais, bissexuais e transgênero de todo tipo". Ao citar a literatura científica sobre mamíferos, aves, anfíbios, peixes, insetos e outros invertebrados, Bagemihl (2000, p. 12) escreve: o "comportamento homossexual ocorre em mais de 450 tipos diferentes de animais no mundo e é encontrado em qualquer região geográfica ou grupo animal de maior escala". Porém, mesmo esse extraordinário catálogo zoológico de animais queers cobre apenas uma pequena parte do universo - ainda que ficássemos apenas com a Terra, há todo um conjunto de criaturas que não cabe na lista, tais como todo tipo de vida não animal (amebas, plantas, vírus) e as muitas formas de existência chamadas por nós de "inanimadas".

Meu argumento é que o mundo em sua exuberância é bem mais queer do que todas as numerosas citações a Haldane aparentam propor. Neste ensaio, considerarei a possibilidade da queeridade de uma das mais ubíquas criaturas - átomos. Essas criaturas "ultraqueers", com suas qualidades quânticas cotidianas, queerizam a queeridade em si em seus modos de existência radicalmente desconstrutivos ${ }^{17}$. Certamente, dado que queer é um questionamento radical da identidade e de binários, incluindo o binário natureza/cultura, este artigo almeja demonstrar que todo tipo de aparente impossibilidade é de fato possível, incluindo a queeridade da causalidade, da matéria, do espaço e do tempo. Queer é um organismo vividamente mutante, uma abertura radical desejante, uma multiplicidade diferenciante, uma des/continuidade agencial, espaçotemporalidade dobrada e inventiva, reiteradamente materializante e promíscua. E se a queeridade fosse entendida não como residente nos interstícios de natureza/cultura per se, mas na própria natureza da espaçotempomaterialização?

Concluindo este prelúdio, gostaria de agradecer às amebas, camaradas excepcionais capazes de cooperar por longas distâncias e alcances na história, por me auxiliarem a entrever a difusão subterrânea de culturas moralizantes que disseminam a

\footnotetext{
${ }^{17}$ Ver também Barad (2010). Alguns podem levantar a objeção de que a queeridade necessariamente tem a ver com desejo e de que isso desqualifica átomos, elétrons, espaço e tempo. No entanto, essa objeção, baseada no excepcionalismo humano, implora pela seguinte questão: que forma é essa que o desejo deve tomar que somente alguns seres ou formas de existência estejam habilitados a ele e não outros?
}

Vol. 03, N. 11, Jul. - Set., 2020 - http://periodicoscientificos.ufmt.br/ojs/index.php/rebeh/index 
doença do ódio genocida e negligenciam ecologias da diversidade necessárias por

florescer. Este é o caso quando a indignação moral escoa pelos alicerces da sociedade.

\section{Performativida queer da natureza ${ }^{18}$}

Um grupo heterogêneo de colaboradores queers - amebas sociais, células neurorreceptoras em arraias, raios, uma espécie fantasma de dinoflagelados, acadêmicos (uma estranha espécie companheira) e átomos, dentre outros - auxiliam na discussão da performatividade queer da natureza. A abordagem utilizada, aqui, não é convidar outros não humanos à "dobrar a queeridade", mas interrogar os binários que suportam as divisões que vínhamos discutindo. Portanto, antes que eles façam sua entrada, algumas questões preliminares devem ser colocadas, incluindo uma discussão mais profunda de como a divisão natureza/cultura, especialmente a fantasia específica do excepcionalismo humano, negligencia tentativas de pensar e fazer crescer ecologias da diferença que tenham a chance de florescer. Já que a própria natureza da espaçotempomaterialização está em questão, vamos começar reiterando.

"Atos contra a natureza" - que imagens bestiais são conjuradas por essa frase? Quando "atos contra a natureza" são cometidos, os crimes não são de menor escala. A indignação moral escorre à frente, como amebas pelo solo do Texas, e vidas estão em questão, talvez literalmente ${ }^{19}$. Que tipos de atos contra a natureza inspiram ultraje moral?

\footnotetext{
${ }^{18} \mathrm{O}$ restante deste ensaio (exceto o primeiro parágrafo da seção intitulada Performatividade Queer da Natureza) é a versão final do ensaio Nature's Queer Performativity, tal como submetido ao periódico Qui Parle. Infelizmente, esta não é a versão que Qui Parle enviou para publicação e tentativas de desfazer o erro fracassaram.

${ }^{19} \mathrm{Na}$ versão original, havia uma nota de rodapé descrevendo a notícia do The New York Times intitulada "Escorre pelo solo do Texas um time de bilhões de amebas". Aquela (parte da) nota de rodapé tornou-se a inspiração para a seção de abertura deste ensaio e foi, assim, removida. A invocação de "stake" conjura um sentido historicamente importante da palavra relevante para a discussão aqui: o fato histórico de que "atos contra a natureza" foram ativamente penalizados pela Igreja durante a Idade Média e de que uma forma de punição capital usada era ser queimado na fogueira (stake). Por um lado, poderíamos chamar isso de um ato inconsciente. Por outro, sem negar a existência do inconsciente, mas dado que vamos trabalhar a questão da comunicação neste ensaio, podemos nos perguntar qual é o mecanismo dessa reverberação, dessa excitação de significado. Além disso, está em questão um emaranhamento (de tempo e de espaço) que é inerente à materialidade da lembrança antes que outra característica única para o humano. Ou, pelo menos, esta torção da história comum é o tipo de reconfiguração humana/não humana que este ensaio espera provocar. Nota de revisão: at stake tem como traduções possíveis tanto "em questão" - como na versão traduzida no corpo do texto - quanto o sentido evocado por Barad nesta nota de rodapé, mas trata-se de um jogo impossível de ser mantido em português.
}

Vol. 03, N. 11, Jul. - Set., 2020 - http://periodicoscientificos.ufmt.br/ojs/index.php/rebeh/index 
Prazeres queer, com certeza, mesmo algumas formas de sexo heterossexual e uma infinidade de outras práticas humanas. A divisão natureza/cultura está obviamente em jogo, mas a lógica que tenta segurá-la em seu lugar é bastante perversa. Por um lado, está claro que humanos são entendidos como atores, os perpetradores desses "atos contra a natureza". O senso de exterioridade é absoluto: o crime é contra a Natureza em si, contra tudo que é natural. A Natureza é a vítima, a vitimada, a quem foi feito o mal. Ao mesmo tempo, os humanos que cometem "atos contra a natureza" supostamente estariam agindo como animais. Em outras palavras, o perpetrador é visto como um danificador externo à natureza, porém ao mesmo tempo é condenado por tornar-se parte da Natureza. A bestialidade é, certamente, uma infração tanto dita quanto não dita, mas o "crime real", como os acusadores diriam, é a violação da divisão natureza/cultura, que não foi simplesmente rompida, mas prejudicada. Dito de outra forma, aqueles que processariam os "perpetradores" por "crimes contra a natureza" tropeçam pela própria divisão que procuram garantir. Para piorar a situação, "atos contra a natureza" que realmente merecem uma resposta enfurecida pelas graves injustiças praticadas são tradicionalmente excluídos da contagem de infrações dentro da (i)lógica dessa prática moralizante. Um caso em questão: dadas as rotineiras associações de humanos com a cultura e de animais com a natureza, pode-se pensar que formas de violência contra animais perpetuadas pela produção industrial de carne - isto é, o extermínio em massa dos "Outros" matáveis qualificar-se-iam nesta lógica como "atos contra a natureza" dignos de ultraje moral ${ }^{20}$. No entanto, são atos sexuais específicos que são criminalizados e taxados como imorais, enquanto o extermínio em massa de animais sequer é digno de nota ou de punição, mas, antes, normalizado, naturalizado e higienizado como parte "inescapável" da produção de comida. Se a lógica falha, que dificuldade na divisão natureza/cultura está sendo indicada neste momento em que a teoria queer e a crítica ecológica se encontram?

A performatividade tem sido essencial para a teoria queer ${ }^{21}$. Ainda assim, a performatividade tem sido retratada (quase exclusivamente) como uma questão do sujeito

\footnotetext{
${ }^{20}$ Para a importante noção de uma ética de "fazer matável", ver Haraway (2008).

${ }^{21}$ Ver especialmente os trabalhos clássicos de Butler (1990,1993) e de Sedgwick (1995, 2003, 2005) e o legado produtivo queer desse engajamento significativo com a noção de performatividade.
}

Vol. 03, N. 11, Jul. - Set., 2020 - http://periodicoscientificos.ufmt.br/ojs/index.php/rebeh/index 
humano; humanos são seu objeto, sua única preocupação 22 . Porém, o excepcionalismo humano é um alicerce esquisito para construir uma teoria que especificamente pretende dar conta de questões de abjeção e da constituição diferencial do humano, ainda mais quando gradações de humanidade, incluindo inumanidades, são frequentemente constituídas na relação com não humanos.

Um caso nesse sentido é a bem-conhecida tática de desumanização - através da identificação de um grupo oprimido de humanos com não humanos menosprezados "pela qual [se torna] possível não apenas destacar um grupo como inimigo, mas também exterminá-lo com a consciência tranquila" (MAMDANI, 2001 apud RAFFLES, 2006, p. $521)^{23}$. Heinrich Himmler, chefe da SS, força de elite nazista, era afeito a essa tática. Ele é fortemente explícito quanto às consequências que tais equivalências são instadas a efetuar:

Antissemitismo é exatamente o mesmo que matar piolhos. Livrar-se deles não é uma questão ideológica. É uma questão de limpeza. Da mesma forma, para nós, o antissemitismo não é uma questão de ideologia, mas uma questão de limpeza que em breve terá sido resolvida. Seremos despiolhados. Restam apenas 20 mil piolhos, e então a questão se resolve em toda a Alemanha (HIMMLER, 1943 apud RAFFLES, 2006, p. 521, grifos meus).

Os efeitos de tais identificações ou equivalências (re)forçadas entre humanos e não humanos outrificados têm sido e continuam a ser devastadores na vida humana. Ao mesmo tempo, seríamos relapsos se o reconhecimento da constituição diferencial de humanos em relação a não humanos somente servisse para centralizar nossa atenção, mais uma vez, exclusivamente em humanos.

Uma resposta ao tipo de aritmética genocida usada por Himmler tem sido rejeitar tais comparações ao invocar a singular superioridade de humanos. No entanto, essa reação não só deixa de lado a relação de equivalência por reforçar a desvalorização de um lado da equação - o não humano em detrimento do humano -, mas o faz repetindo o mesmo

\footnotetext{
${ }^{22}$ Engajamentos com a teoria da performatividade que explicitamente desafiam seu foco no humano incluem Barad (2003, 2007), Birke, Bryld e Lykke (2004), Giffney e Hird (2008), Kirby (1997, 2006) e Schrader (2010).

${ }^{23} \mathrm{O}$ relatório Stanton sobre estágios de genocídio identifica a desumanização (o estágio 3 ) como um estágio marcado pela identificação de grupos humanos com não humanos. Cachorros, ratos, baratas, piolhos, vermes, insetos e parasitas são comumente listados com os desprezados outros para esse propósito.
}

Vol. 03, N. 11, Jul. - Set., 2020 - http://periodicoscientificos.ufmt.br/ojs/index.php/rebeh/index 
cálculo de racialização empregado. Esse tipo de resposta ecoa o problema que pretende resolver, subscrevendo uma posição ética e moral de apagamento - uma inabilidade de considera $^{24}$ as (inevitáveis) exclusões constitutivas encenadas. Isto é, a relação de equivalência entre humano e não humano é cancelada em proposições como essa, mas somente por elidir as condições materiais e os efeitos de como diferentes diferenças chegam à matéria ${ }^{25}$. A dimensão que é apagada é a matabilidade não questionada de não humanos. Não humanos não figuram nesse tipo de cálculo moral ${ }^{26}$. Contudo, as posições contrárias - a reafirmação da equivalência entre humanos e não humanos em nome dos direitos animais ou o privilégio dos direitos animais sobre os direitos humanos (ao inverter a frequente desigualdade que toma como certa a superioridade humana) sustentam-se nos mesmos tipos de dificuldades e não fazem nada mais para promover a considerabilidade $^{27}$.

É necessário um ponto de partida para análise que não presuma que os termos de qualquer lado das relações de equivalência são dados, mas que em vez disso tome a matéria dos cortes que produzem distinções entre "humanos" e "não humanos" - nas quais a constituição diferencial de ambos os termos é importante, assim como suas respectivas exclusões constitutivas -, antes que quaisquer comparações se iniciem. Em

\footnotetext{
${ }^{24}$ Nota da revisão: accountability, traduzido, aqui, por considerabilidade e seus derivados, tem um sentido político importante retomado diversas vezes pelo ensaio. Pode ser lido simultaneamente como habilidade de levar em conta, de perceber e responder ao outro.

${ }^{25}$ Nota da revisão: é sabido que matter tem um duplo sentido em inglês: quando tratado como verbo, o primeiro sentido é de o "materializar" e o segundo de é "importar"; se tomado como substantivo, o termo ainda pode significa simultaneamente matéria e questão. Esta duplicidade é impossível de ser vertida em português e as diversas traduções do termo no debate sobre performatividade no Brasil tem indicado neste sentido. Para demarcar o jogo da autora, nós usamos esses sentidos em diferentes momentos do texto e, eventualmente, recorremos a tradução "chegar à matéria", proposta por Therezinha Rocha, tradutora de Barad (2017).

26 "Mas o que fazer da morte dos animais? É uma morte 'como tal' e eles a acessam, ou talvez nós por eles? O que de fato a morte de um animal pode fazer por nós, não em termos de alimentação ou vestuário, mas há algum 'conhecimento' ganho por ver um animal morrer ou mesmo por matá-lo? A questão vem parcialmente do que sabemos sobre a relativa invisibilidade do enorme número de assassinatos de animais que acontecem nos abatedouros, laboratórios científicos e abrigos animais - assassinatos que, antes de meados do século XIX, frequentemente ocorriam sob nossos olhos, nas ruas ou nas cozinhas" (WELL, 2006 , p. 90). Recentemente, nós temos presenciado um aumento agudo no reconhecimento da matança em massa de animais, que esteve ignorada. Ver, por exemplo, Derrida (1991, 2008), Wolfe (2003), Sztybel (2006), Spiegel (1997) e Agamben (1999, 2004).

${ }^{27}$ Quando consideração e considerabilidade estão em questão, é importante estar atento a qualquer matemática subjacente. Note que a vulnerabilidade constitutiva do outro abjeto não necessariamente se baseia na existência de classificações hierárquicas. Relações de equivalência podem também estar efetivamente envolvidas.
}

Vol. 03, N. 11, Jul. - Set., 2020 - http://periodicoscientificos.ufmt.br/ojs/index.php/rebeh/index 
outras palavras, é necessário levar em consideração os cortes que são feitos e os emaranhamentos constitutivos que são efetuados. Em particular, a questão "póshumanista" não é borrar as fronteiras entre humano e não humano, não é eliminar toda e qualquer distinção e diferença e finalmente não é simplesmente inverter o humanismo, mas compreender os efeitos materializantes de modos particulares de desenhar fronteiras entre "humanos" e "não humanos"28. De forma crucial, tal análise não pode imaginar cortes puramente como matéria de práticas humanas de diferenciação, ou seja, de distinções culturais. Seja o "corte" o que for, ele não deve assumir uma noção a priori de "humano".

Alternativamente, poderíamos perguntar: e o que acontece ao não humano quando se leva em consideração as implicações performativas de abjeção, subjeção, agência e materialização? Certamente não humanos, assim como humanos, não podem ficar de fora, mas ampliar o alcance de aplicabilidade da performatividade para incluir não humanos não é o que está em questão. Em vez disso, o ponto é que as práticas de diferenciação do "humano" em relação ao "não humano", do "animado" em relação ao "inanimado" e do "cultural" em relação ao "natural" produzem efeitos materializantes cruciais que não estão sendo levados em consideração quando uma análise é iniciada após essas fronteiras serem estabelecidas. Em outras palavras, o que é necessário é levar em consideração não só a materialização de corpos "humanos", mas todos os processos de chegar à matéria(ação)/materialização, incluindo os efeitos materializantes das práticas que fazem as fronteiras pelas quais o "humano" e o "não humano" são diferencialmente constituídos. Isso deve incluir não só forças naturais e sociais, mas a constituição diferencial de forças como "naturais" ou "sociais" 29.

Consequentemente, minha preocupação, aqui, não é a performatividade não humana por si, mas as práticas materializantes de diferenciação, nas quais não se pode considerar que todos os atores, ações e efeitos são humanos. São de interesse, assim, não

\footnotetext{
${ }^{28}$ Uma abordagem pós-humanista põe em questão qualquer caráter "dado" das categorias diferenciais de "humano" e de "não humano", examinando práticas a partir das quais essas fronteiras diferenciais são estabilizadas e desestabilizadas (BARAD, 2003). A noção de "efeito" e de relações causais de maneira mais geral é trabalhada aqui.

${ }^{29}$ Em outras palavras, um elemento de análise é repensar a performatividade (humanista), não simplesmente ampliar sua aplicabilidade. Isso inclui compreender performatividade como intra-atividade iterativa antes que citacionalidade iterativa.
}

Vol. 03, N. 11, Jul. - Set., 2020 - http://periodicoscientificos.ufmt.br/ojs/index.php/rebeh/index 
só as práticas pelas quais os humanos fazem distinções, mas também as práticas de diferenciação nas quais não humanos se engajam, através das quais não humanos diferenciam-se de seus ambientes, de outros não humanos e dos humanos, assim como dos outros outrificados Para ser mais precisa, o ponto é não meramente incluir não humanos ou humanos como atores ou agentes de mudança, mas encontrar caminhos para pensar sobre a natureza da causalidade, da agência, da relacionalidade e da mudança sem tomar essas distinções como fundacionais ou estáveis. É necessário, portanto, um modo de pensar sobre a natureza da diferenciação que não seja derivado de uma noção fixa de identidade ou mesmo de espacialização. De fato, qual é a natureza da diferença se a diferenciação não ocorre no espaço e no tempo, mas na produção da espaçotempomaterialização ${ }^{30}$ ? Que estranha causalidade opera em construções performativas? Que temporalidade constitui (e/ou é constituída por) essa operação? O que significa para as exclusões constitutivas ser parte da própria fabricação de espaçotempomaterialização?

Em outro lugar, ofereci uma exposição detalhada de uma abordagem performativa pós-humanista do processo de materialização que não limita suas preocupações e análises ao escopo do humano ${ }^{31}$. Em minha abordagem realista agencial, todos os corpos, não apenas os humanos, materializam-se através da performatividade do mundo - sua intra-atividade iterativa ${ }^{32}$. A matéria não é apresentada como mero efeito ou produto de práticas discursivas, mas como fator agente em sua materialização iterativa e, por efeito, a identidade e a diferença são radicalmente retrabalhadas. Em particular, argumentei que aquilo que tomamos frequentemente como entidades individuais não são objetos separados com limites rígidos e proprietarizados, mas são ("partes" emaranhadas de) fenômenos (intra-ações materiais-discursivas) que se estendem atravessando (o que comumente tomamos como lugares e momentos separados no) espaço e tempo (nos quais noções de "material" e "discursivo" e a relação entre eles são desamarradas de seus fundamentos anti/humanistas e retrabalhadas). Fenômenos são emaranhamentos de espaçotempomaterialização, não no sentido corriqueiro de uma conexão ou

\footnotetext{
${ }^{30}$ O termo "espaçotempomaterialização" (sem os usuais hífens para separar os substantivos) refere-se à natureza emaranhada do que é geralmente tomado como aspectos separados. Ver Barad (2007).

${ }^{31}$ Ver Barad (2003, 2007).

${ }^{32}$ Para contrastar com a noção de performatividade de Butler (1993) como citacionalidade iterativa.
}

Vol. 03, N. 11, Jul. - Set., 2020 - http://periodicoscientificos.ufmt.br/ojs/index.php/rebeh/index 
intercruzamento de entidades individuais, mas no sentido técnico de "emaranhamentos quânticos", que são a inseparabilidade (ontológica) de "componentes" agencialmente intra-ativos ${ }^{33}$. A noção de intra-ação (em contraste ao termo usual "interação", que presume a existência prévia de entidades/termos independentes) marca um deslocamento importante, reabrindo e reconfigurando noções fundacionais de ontologia clássica como causalidade, agência, espaço, tempo, matéria, discurso, responsabilidade e consideração. Uma intra-ação específica encena um corte agencial (em contraste com o corte cartesiano - uma distinção inerente entre sujeito e objeto) efetuando uma separação entre "sujeito" e "objeto". Isto é, o corte agencial encena uma resolução "local” por dentro do fenômeno de indeterminação ontológica ${ }^{34}$ inerente. De forma crucial, intra-ações encenam separação agencial - a condição local de exterioridade-dentro-do-fenômeno. Assim, a diferenciação não é uma relação de exterioridade radical, mas de separabilidade agencial, de exterioridade-dentro. Intra-ações cortam coisas junto-separadas (em um único movimento). Identidade é matéria fenomênica; não é uma questão individual. Identidade é múltipla em si mesma; ou, posto de outro modo, identidade é difratada através de si-identidade é difração/différance/diferir/deferir/diferenciação ${ }^{35}$.

Neste artigo, eu quero explorar mais essas questões ao considerar os atos da natureza - isto é, a intra/atividade da natureza, sua performatividade queer - que fazem alianças e, assim, nos enxergar como sempre já parte da natureza, considerando todo modo de existência que a categoria "atos contra a natureza" pretensamente salvaguarda ou defende, mas na verdade apaga e demoniza. Na próxima seção, eu introduzo algumas “criaturas queer". Referir-se a elas como queer não é usar um termo da moda quando "estranho" ou "esquisito" seria suficiente, nem fazer uma explanação sobre como essas criaturas se engajam em práticas sexuais queer (embora algumas o façam), mas, na verdade, é chamar atenção para o fato de que seu "ser espécie", por assim dizer, explicita

\footnotetext{
${ }^{33}$ Fenômenos são relações ontologicamente primitivas - relações sem termos prévios a ela. Isto é, relações não são derivadas secundariamente de termos existentes independentemente, mas a dependência ontológica mútua dos termos - a relação - é o primitivo ontológico. Os termos só existem dentro dos fenômenos como resultado de intra-ações específicas (isto é, não há termos independentes, somente termos-dentro-derelações).

${ }^{34}$ Em outras palavras, termos não preexistem às relações; em vez disso, termos-dentro-de-fenômenos emergem através de intra-ações específicas.

${ }^{35}$ Difração, como fenômeno físico, envolve emaranhamento/sobreposição de diferentes tempos e espaços. Ver Barad (1993).
}

Vol. 03, N. 11, Jul. - Set., 2020 - http://periodicoscientificos.ufmt.br/ojs/index.php/rebeh/index 
a queerização da "identidade" e da relacionalidade ${ }^{36}$ (não é suficiente dizer que a identidade é uma relação, se a relação em questão é entre entidades que são entendidas como prévias à relação).

Falar de "criaturas queer" é atravessar os cortes que definem esses termos. Por um lado, podemos entender "queer" como um verbo 37 agindo no substantivo "criatura". A queerização da criatura é importante, posto que o termo criatura já encena exclusões que, neste artigo, vêm sendo problematizadas. Criatura, em um sentido do termo, é um ser animado, onde a linha entre animado e inanimado é tomada como dada, não como efeito de práticas particulares de "fazer fronteiras". Por outro lado, "criatura" é já internamente queer, apresentando associações contrárias posto ser um termo definido tanto em contraste com ou distinto de humanos (como em sua referência a não humanos animados) quanto em relação a humanos (por exemplo, como um termo de reprovação ou desprezo, mas também às vezes como um termo de afeto ou ternura) ${ }^{38}$. Em um sentido importante, criaturas são inerentemente desestabilizadoras e não possuem identidades determinadas, por definição.

\section{Criaturas queer, causalidade quântica e a performatividade da natureza}

As criaturas queer introduzidas nesta seção incluem o raio, células neurorreceptoras em arraias, uma espécie fantasma de dinoflagelados, acadêmicos (uma espécie estranha) e átomos. Manter o olhar (ou, se você é uma serpente-do-mar, todo o seu ser) atento às suas capacidades de comunicação pouco clássicas, ou mais precisamente, às bizarras relações causais que elas exibem como resultado da natureza

\footnotetext{
${ }^{36} \mathrm{O}$ ponto não é meramente que a identidade é múltipla ou fluida, mas que a identidade em si está em questão no que e no que não pesa, onde a considerabilidade é parte de relações ético-ontológicas e de emaranhamentos de mundificação.

${ }^{37}$ Nota da revisão: Barad faz referência à locução "queer critters", que pode ser lida em inglês tanto como "queerizar criaturas" quanto como "criaturas queer".

${ }^{38}$ OED Online: "criatura (critter)", variação informal de "criatura (creature)". "Criatura (creature)": 2. a. Uma "criatura" viva ou um ser criado, um ser animado; um animal; em geral com distinção em relação a "homem". 3. a. Um ser humano; uma pessoa ou indivíduo (como em 'cada criatura no quarto'). Comum na frase "nossas criaturas companheiras". b. com qualidades expressando (a) admiração, aprovação, afeto ou ternura (às vezes, como brincadeira); (b) compaixão ou comiseração (às vezes com um tom de amparo). c. Expressando reprovação ou desprezo. Disponível em http://dictionary.oed.com .Nota da revisão: sem data de acesso ao original.
}

Vol. 03, N. 11, Jul. - Set., 2020 - http://periodicoscientificos.ufmt.br/ojs/index.php/rebeh/index 
fenomênica/emaranhada de suas existências, ajudará a tornar evidente a natureza agencialmente intra-ativa (isto é, performativa e queer) de seu devir ${ }^{39}$.

Ao engajar nossas colaboradoras queer, é crucial que nos lembremos de que o ponto não é meramente usar não humanos como ferramentas com as quais podemos pensar, mas pensar com elas para enfrentar nossas obrigações éticas para com elas, já que não são meras ferramentas para nosso uso, mas seres vivos reais (e incluo nessa categoria seres "inanimados" e "animados" $)^{40}$. Outro ponto relacionado a esse é evitar a armadilha de posicionar tudo em relação ao humano e abraçar um compromisso de sermos atentas à atividade de cada criatura em seu engajamento contínuo e intra-ativo com e como parte do mundo que ajuda a materializar.

\section{A conversa balbuciante do raio}

O raio inspira medo e reverência. Ele sacode nossas memórias, suscitando imagens brilhantes das origens elétricas da vida em nossos olhos: imagens do salto energético do raio apresentam-se, sua revivificação do lodo primordial ao ser chocado com uma sopa de matéria orgânica para preparar os primeiros organismos da Terra; imagens da natureza destruída em meio à usurpação do poder de dar vida pelo homem. Imagens conhecidamente animadas pelo monstro do Dr. Frankenstein. O raio dá vida e a leva embora.

O raio é um fenômeno impactante. É um arquetípico "ato da natureza" causando "mais mortes diretamente do que qualquer outro fenômeno climático" (UMAN, 1986, p. 17). Aproximadamente 10 mil incêndios florestais nos EUA são iniciados por raios todos os anos (Uman, 1986, p. 5). De acordo com o National Weather Service, "a qualquer

\footnotetext{
${ }^{39}$ Ver Barad (2007) para mais detalhes do sistema de fotorrecepção único da serpente-do-mar. Serpentesdo-mar são algumas das minhas outras colaboradoras queer.

${ }^{40}$ Haraway entranhou em nós a necessidade de considerar nossas obrigações éticas. Seu persistente questionamento da fronteira humano/ não humano teve um enorme impacto no campo dos "estudos animais" (bem antes de existir um campo com esse nome) e além. Onde estariam a crítica ecológica, os estudos feministas da ciência, os estudos da ciência e da tecnologia, a teoria feminista e os demais sem as suas intervenções? A linha entre animado e inanimado talvez seja a menos questionada e a mais confortável de todas (pelo menos para humanos, certamente não para as serpentes-do-mar). Ironicamente, isso ecoa o privilégio atual do biológico sobre o físico nos nossos imaginários tecnocientíficos, na cultura mais ampla assim como nos estudos culturais e nos estudos animais. Uma reverberação desse preconceito cultural é a categoria "não humano" ser frequentemente assumida como equivalente à categoria "animais não humanos".
}

Vol. 03, N. 11, Jul. - Set., 2020 - http://periodicoscientificos.ufmt.br/ojs/index.php/rebeh/index 
momento, há 1800 tempestades de raios e trovões em algum lugar da Terra”, ou aproximadamente 16 milhões de tempestades similares anualmente ${ }^{41}$.

Raios são tanto uma ocorrência cotidiana quanto um fenômeno complexo em si mesmo, desafiando cientistas em sua compreensão da física em diversas ocasiões. Outra de minhas colaboradoras, a teórica pós-estruturalista Vicki Kirby, elegantemente anima a natureza queer das performances do raio:

Como moro em uma espécie de paisagem cujo panorama inclui uma parte significativa do porto e do horizonte de Sydney, é comum ver trovoadas surgindo pela cidade. Enquanto esperava pelo próximo lampejo, tentando adivinhar onde iria acertar, eu me perguntava sobre a lógica errática dessa carga ardente, cuja intenção parece tão inconstante quanto determinada. A pressuposição de que o raio exibe uma certa lógica é evidente no senso comum de que um raio nunca acerta o mesmo lugar duas vezes. Porém, como nos conta Martin Uman, um dos maiores intérpretes de raios, a situação é um tanto oposta. "Muito do que se sabe sobre raios hoje foi descoberto precisamente porque o raio acerta a mesma estrutura de novo e de novo... O Empire State Building na cidade de Nova York é acertado por raios em média 23 vezes por ano" (UMAN, 1986, p. 47). Ao ler sobre a predileção da eletricidade por prédios altos, árvores isoladas em campos de golfe, tratores e corpos de água abertos, também aprendi que curiosos ritos de iniciação precedem esses encontros elétricos. Uma comunicação intrigante, um tipo de conversa balbuciante entre a terra e o céu, parece antecipar o lampejo. Um exemplo espetacular é o fogo de santelmo, um espetáculo luminoso visível que pode algumas vezes ser visto animando-se em um objeto no momento imediatamente antes do disparo [...].

Mas vamos começar com algo cujo comportamento esperamos que seja mais direto do que a natureza controversa do fogo de santelmo e sua associação com "esferas luminosas móveis chamadas raios globulares" "42. Por exemplo, se começarmos por considerar um raio comum, o clarão que estamos acostumados a observar em uma trovoada, nós provavelmente assumiríamos que o raio se origina da nuvem, então é descarregado na direção do solo. Entretanto, se essa causalidade direcional fosse verdadeira, seria razoável perguntar como o raio pode ser informado de sua rota mais econômica até o solo antes que isso fosse testado. De acordo com especialistas, o caminho do raio é o de uma disjunção em arco que corre numa direção tanto "para cima" quanto "para baixo" (UMAN, 1986, p. 73). Prédios e outros objetos no chão podem iniciar os "disparos" ao enviar as chamadas "descargas conectantes" de convite a uma fagulha descendente visualmente indetectável chamada líder escalonado - ou vice-versa. Uman explica esse momento de iniciação em termos similares aos "atos de fala". "O que é importante notar [...] é que o lider escalonado comum começa da nuvem sem nenhum 'conhecimento' de que prédios ou de que geografia está presente abaixo. Na verdade, acredita-se [...] que o lider escalonado não fica 'ciente' dos objetos abaixo até que esteja a algumas dezenas de metros

\footnotetext{
41 National Weather Service, "Lightning Safety". Disponível em: http://www.lightningsafety.noaa.gov/science.htm. Nota da revisão: sem data de acesso no original.

${ }^{42}$ Kirby adiciona em uma nota de rodapé: "apesar do título do livro de Peter Coleman (1998) sobre essa questão, Ball Lightning: A Scientific Mistery Explained, a literatura indica que o raio globular é uma matéria controversa e sua abordagem permanece inconclusiva".
}

Vol. 03, N. 11, Jul. - Set., 2020 - http://periodicoscientificos.ufmt.br/ojs/index.php/rebeh/index 
de seu eventual ponto de disparo. Quando tal 'ciência' ocorre, uma fagulha viajante é iniciada do ponto de disparo e se propaga para cima até encontrar-se com o líder escalonado movendo-se para baixo, completando o caminho até o chão" (p. 49-50). Podemos nos perguntar que linguagem conduz essa "conversa elétrica" que parece precipitar-se a si mesma no instante final (ou foi esse o primeiro instante?) de apreensão divina "quando a 'ciência' mútua acontece"? (KIRBY, 2011, p. 10-11).

Que tipo de comunicação bizarra está funcionando aqui? Que estranha causalidade é efetuada? Um raio não é a resolução direta do acúmulo de diferença de carga entre a terra e uma nuvem de tempestade: um raio não procede simplesmente da nuvem para a terra ao longo de um caminho unidirecional (talvez, um tanto errático). $\mathrm{O}$ caminho que o raio percorre é não só imprevisível, mas ele também não acontece de modo contínuo entre céu e terra. Existe, por assim dizer, algum tipo de comunicação não local efetuada entre os dois. Por algum mecanismo que cientistas ainda precisam explicar mais profundamente, uma nuvem de tempestade torna-se extremamente polarizada - elétrons saltam de átomos aos quais estavam previamente ligados e se agregam na parte mais baixa da nuvem, o mais próximo possível da terra. Em resposta, a superfície da terra torna-se também polarizada com elétrons movendo-se para dentro da terra. Um forte campo elétrico entre terra e nuvem é gerado e tudo que resta para ser realizado é um caminho condutivo entre as duas. Os primeiros indícios de um caminho têm um começo modesto, sem indicação de seu fim explosivo.

Começa como uma pequena fagulha dentro da nuvem oito quilometros acima. Um fluxo de elétrons corre para fora, viaja cem metros, depois para e se acumula por alguns microssegundos. Em seguida, o fluxo segue em uma direção diferente, junta-se novamente e novamente. Frequentemente, o fluxo se ramifica e se divide. Ainda não é um raio (Discovery Channel, 2007) ${ }^{43}$

Esses primeiros gestos pouco luminosos são chamados líderes escalonados. No entanto, o acúmulo de carga negativa (elétrons) na porção mais baixa da nuvem não se termina por ser um canal direto de elétrons, fazendo seu caminho até a terra. Em vez

\footnotetext{
${ }^{43}$ Todas as citações deste parágrafo são do programa de televisão Discovery Wonders of Weather: Lightning Phenomena do canal Discovery Channel (setembro, 2007). Disponível em: http://science.howstuffworks.com/nature/natural-disasters/lightning.htm. Nota da tradução: sem data de acesso no original. Optamos também pelo uso do itálico de forma a destacar o exercício da autora de outras citações realizadas nesta sessão.
}

Vol. 03, N. 11, Jul. - Set., 2020 - http://periodicoscientificos.ufmt.br/ojs/index.php/rebeh/index 
disso, a terra responde em seguida com um sinal ascendente de si mesma. Quando esse líder escalonado está a dez ou cem metros do solo, o solo agora está ciente de que há um grande excedente de carga, e certos objetos na terra respondem lançando pequenas serpentinas em direção ao líder escalonado, filamentos de plasma fracamente luminosos, que estão tentando se conectar com o que está descendo. É como se objetos no chão fossem convocados pelo endereçamento interpelativo da nuvem. Quando uma das respostas ascendentes é atendida pelo endereçamento descendente, o circuito elétrico é fechado e uma descarga poderosa é efetuada na forma de um raio. No entanto, mesmo depois do caminho traçado, por assim dizer, a descarga não procede de modo contínuo: A parte do canal mais próxima do chão irá escoar primeiro, então sucessivamente as partes mais altas até finalmente a carga da nuvem em si. Então o raio visível se move do chão para a nuvem, enquanto a corrente elétrica flui de maneira descendente.

Uma resposta à diferença animadora e até vívida, se quisermos mencioná-la. Que mecanismo está em ação nessa troca comunicativa entre céu e terra quando a ciência mútua está no cerne desse relacionamento inanimado estranhamente animado? Como essa troca se antecipa, por assim dizer? Como o solo é animado para a ciência de seu possível interlocutor? E o que significa para o remetente transmitir uma mensagem para um destinatário que é tanto específica para o destinatário em sua conexão localizada exata e ainda assim não especificada no momento de sua transmissão?

O que fazer quando a comunicação não tem nem emissor, nem receptor até que ela já tenha ocorrido? Isto é, o que podemos fazer do fato da existência do emissor e do receptor ser consequência da relacionalidade não local e não sua predecessora? Se o raio habita a fronteira entre vida e morte, se existe na beira da lâmina entre o animado e o inanimado, ele não parece inclinado ora aqui e ora lá em cada lado da divisão ${ }^{44}$ ?

\section{Células neurorreceptoras clarividentes em arraias}

\footnotetext{
${ }^{44}$ Se a noção de campo é chave para uma explicação desse fenômeno, como certamente parece, então o ponto aqui é abrir para exame as características bizarras do campo em vez de fechar a discussão por nomeálo. De todo modo, muitas peças ainda faltam para entender a natureza animada do campo elétrico. Kirby afirma: “"se nuvens de tempestade, mesmo grandes nuvens de tempestade, não possuem campos elétricos grandes o suficiente para gerar o enorme lampejo que é o raio, de onde está vindo toda aquela energia?' Pesquisadores neste ponto não estão reconsiderando a natureza 'do campo' como divisão de polaridades separadas, nem a noção de 'localização', tampouco explicações que presumem uma causa linear. Confrontados pelo problema de encontrar a origem do raio, eles agora estão olhando para o espaço sideral em busca de uma resposta" (KIRBY, 2011, p. 138-139).
}

Vol. 03, N. 11, Jul. - Set., 2020 - http://periodicoscientificos.ufmt.br/ojs/index.php/rebeh/index 
Células neurorreceptoras em arraias parecem possuir "uma clarividência misteriosa":

\begin{abstract}
Elas são capazes de prever quando uma mensagem que ainda vai chegar terá sido endereçada a elas, pois elas se destrancam em prontidão. É como se a identidade e o comportamento de qualquer célula receptora observável fossem esticados de alguma forma ou disseminad, em uma dobra do espaço/tempo. É como se elas estivessem localizadas aqui e lá ao mesmo tempo. Se a separação entre emissor e receptor é estranhamente comprometida neste exemplo biológico, também o é o status da mensagem. Para considerar isso com mais cuidado, se não há intervalo entre os dois, que diferença a mensagem poderia efetuar e qual seria? Coisa estranha essa ação à distância que confunde a lógica da causalidade (KIRBY, 2001, p. 59, grifos meus $)^{45}$.
\end{abstract}

Para que não concluamos que esses dois exemplos de comunicação paradoxal (como exibidos por raios e células neurorreceptoras em arrais), paradoxos que acabam por implicar estruturas de temporalidade e causalidade, se aplicam apenas a alguns poucos fenômenos, vamos ampliar o quadro e mergulhar na história como Kirby conta. Kirby começa essa jornada de conversas neuronais em arraias descrevendo a situação em que se encontra quando recebe este resultado científico surpreendente:

Estava numa fila com um pequeno grupo de pesquisadores, cada um encarregado de explicar nossos vários projetos intelectuais para uma associação de financiadores. Fui convocada a justificar meu entusiasmo pela crítica desconstrutiva a uma audiência não-acadêmica que, propriamente, esperava ouvir de que forma isso poderia ser valorizado em forma de investimentos. Não preciso dizer que estava apreensiva sobre minha habilidade de convencê-los. No entanto, sem nenhum barulho ou fanfarra em particular, a jovem bióloga que falou antes de mim transmitiu eloquentemente o cerne peculiar da minha pergunta. $\mathrm{O}$ objeto de sua paixão especial era a arraia e, se bem me lembro, o interesse dela em como a conversa entre células era facilitada pela observação que as estruturas neuronais dessas criaturas em particular permitiam [...]. Seus ouvintes fascinados foram informados de que as células receptoras, que operam como fechaduras que só podem ser abertas pela tecla ou mensagem certa, parecem possuir alguma clarividência misteriosa (KIRBY, 2001, p. 58-59).

\footnotetext{
45 A noção de "ação à distância" é uma referência ao que é prontamente mais identificado como "emaranhamentos quânticos" e aparece novamente na discussão de performances atômicas à frente.
}

Vol. 03, N. 11, Jul. - Set., 2020 - http://periodicoscientificos.ufmt.br/ojs/index.php/rebeh/index 
Depois de destacar a estranha causalidade evidenciada nesses resultados, Kirby

continua:

Havia, certamente, ouvido isso antes. Sem dúvidas, com alguma perplexidade, percebi que a identidade emaranhada de uma célula na outra havia tomado até proporções humanas em relação à individuação. Essa bióloga sabia desde já dos meus trabalhos intelectuais, antes do nosso encontro, enquanto eu tentava articular os resultados que ela havia inevitavelmente descoberto? Que algoritmo contagiante nos juntou antes mesmo de nosso encontro? (KIRBY, 2001, p. 59).

A abordagem de Kirby desses dois acontecimentos comunicativos não locais engajando-se em uma mistura talvez imprópria (quiçá, escandalosa) de fenômenos em escala e escopo aparentemente diferentes (juntando forças naturais e culturais, como se forças viessem em tipos tão marcadamente diferentes) - não presta nenhuma homenagem às indulgências anti-humanistas e humanistas no excepcionalismo humano. Em seu livro, Quantum Anthropologies, Kirby argumenta em favor de uma leitura materialista da gramatologia de Derrida. Ela considera, por exemplo, que os paradoxos quânticos exibidos por raios, arraias e humanos são persistentemente negados de qualquer valor empírico, como se o pensamento de permitir à natureza tal grau de complexidade ontológica fosse demais para se lidar e que tais matérias desconcertantes devessem, no fim, ser resultado do enquadramento perverso pela cultura de algo significativamente mais manso. Argumentando que a desconstrução deveria ser encarada como ciência positiva, Kirby desenovela a vivacidade do mundo de uma forma que conversa com minha consideração realista agencial da mundificação. Isto é, as relações emaranhadas de naturezacultura não param na intra-ação entre Kirby e a bióloga cujo relato precede o dela num radical "desfazimento" de "precedentes" 46 . Sempre recebendo as intervenções materialistas uma da outra, as leituras materialistas de Kirby da gramatologia de Derrida e as minhas da física quântica repensando a matéria(lização) (tornando evidente o caráter desconstrutivo da física em relação a seus próprios fundamentos clássicos) têm conversado uma com a outra desde antes de nos encontrarmos. Esta colaboração última é uma de uma multidão de performances emaranhadas do mundo mundificando-se.

\footnotetext{
46 Naturezacultura é, sem dúvidas, um dos termos compactados incrivelmente sugestivos de Donna Haraway.
}

Vol. 03, N. 11, Jul. - Set., 2020 - http://periodicoscientificos.ufmt.br/ojs/index.php/rebeh/index 


\section{Performances fantasmas de Pfiesteria}

No verão de 1997 o The Washington Post publicou uma história com uma manchete digna do National Inquirer ${ }^{47}$ : O frenesi alimentar de uma célula transformativa vinda do inferno. $\mathrm{O}$ artigo descreve esses microrganismos demoníacos da seguinte forma:

Criatura, ela mesma invisível tanto para os cientistas quanto para os peixes, uma predadora unicelular bizarra que parece se transformar de animal para planta e vice-versa. Chamada Pfiesteria piscicida, essa dinoflagelada assassina capturou a atenção de cientistas no mundo inteiro quando emergiu seis anos atrás [1991] das trevas dos estuários costeiros da Carolina do Norte, a suspeita fantasma de uma série de extermínios em massa que destruíram mais de um bilhão de peixes (WARRICK, 1997 apud SCHRADER, 2010, p. 175-276).

Dinoflagelados são protistas microscópicos, geralmente unicelulares e fotossintéticos, com flagelos parecidos com chicotes. "Dinos" parecem ser a causa da maré vermelha e são suspeitos de serem tóxicos para certos peixes. Eles não são nem plantas, nem animais, mas podem agir como ambos:

Embora tenha se acreditado que aproximadamente metade das espécies de dinoflagelados descritas aja como plantas fotossintetizadoras e a outra metade seja heterotrófica (obtendo energia alimentando-se de outros organismos), há uma impressão crescente de que muitas espécies são, na verdade, mixotróficas, alternando seus hábitos nutricionais de acordo com as variações ambientais (COATS, 2002, p. 417; HACKETT, et al, 2014, p. 1523). Também a depender das condições ambientais, dinoflagelados podem mudar sua forma de reprodução, frequentemente assexuada, mas nem sempre. "Uma fase sexual foi documentada para muitos dinoflagelados e envolve a fusão de gametas gerados assexuadamente para produzir um zigoto móvel, o planozigoto". (COATS, 2002, p. 418). ${ }^{48}$

Uma espécie tóxica de dinos - Pfiesteria piscicida ("assassina de peixes") chamou a atenção da pesquisadora de estudos da ciência Astrid Schrader ${ }^{49}$. Schrader explica que um tipo de "histeria de Pfiesteria" estabeleceu-se na comunidade científica, que não conseguiu identificar as mais básicas características de Pfiesteria depois de mais de duas décadas de pesquisa. Não há acordo tanto sobre o ciclo de vida de Pfiesteria, nem

\footnotetext{
${ }^{47}$ Nota da revisão: nome de um tabloide estadunidense.

${ }^{48}$ Trecho de uma versão anterior e não publicada de Scharader (2010), usada, aqui, com a permissão da autora.

${ }^{49}$ Ver Schrader (2008a; 2008b; 2010).
}

Vol. 03, N. 11, Jul. - Set., 2020 - http://periodicoscientificos.ufmt.br/ojs/index.php/rebeh/index 
se elas são os agentes responsáveis pela morte de milhões de peixes e por grandes danos e destruição de estuários. Longe de ser apenas matéria de curiosidade científica, as preocupações reais, aqui, em voga têm implicações econômicas e ecológicas em escala global $^{50}$.

A falta de consenso científico sobre as características inerentes de Pfiesteria incitou responsáveis por políticas públicas a adotar uma postura "ver-e-esperar". No entanto, Schrader adverte que essa posição (alegadamente uma não-posição) é tão perigosa quanto desinformada, já que é baseada em um erro grosseiro em relação à natureza da ciência: os responsáveis pelas políticas (e a maioria dos cientistas) acreditam que a falta de evidência definitiva necessariamente marca uma incerteza, um intervalo no estado atual de conhecimento que em breve deverá ser completado. Em vez disso, examinando diferentes práticas laboratoriais em detalhe, Schrader argumenta que o fato de os cientistas não terem conseguido desvendar a natureza de Pfiesteria tem precisamente a ver com a natureza da criatura em si - dado que seu "ser espécie" é indeterminado. Dito de outro modo, Schrader aponta que aquilo que os cientistas e políticos tomam como incerteza epistemológica trata-se na verdade de indeterminação ontológica: "Os seres das espécies de Pfiesteria não são simplesmente fluidos ou múltiplos, redutíveis a variações em um continuum preconcebido de tempo, mas inerentemente indeterminados. Não há um momento no tempo em que Pfiesteria poderia ser isolada sem ambiguidades de seu meio" (SCHRADER, 2008b, s/p). Schrader expõe seu argumento da seguinte maneira:

Além da inseparabilidade de "organismo" e "ambiente", mudanças espaciais (síncronas) e temporais (diacrônicas) na história de vida de Pfiesteria estão completamente imbricadas. Não há momento no tempo em que Pfiesteria

\footnotetext{
${ }^{50}$ Pensa-se que as Pfiesteria são as causadoras das marés vermelhas, ou do que vem sendo chamado de HABs (florações de algas nocivas). "Florações de algas são consideradas nocivas de dois modos distintos que, no entanto, se sobrepõem - pela alta produção de biomassa e pela produção de toxinas. De maior preocupação para ecólogos marinhos são microrganismos chamados dinoflagelados [...] Um aumento explosivo de biomassa de algas pode levar à expansão das chamadas "zonas mortas". Zonas mortas são zonas pouco concentradas em gás oxigênio no oceano. Quando quantidades excessivas de algas não podem mais ser consumidas por predadores, seus corpos afundam até as partes mais profundas dos oceanos, onde bactérias trabalham na sua decomposição. As bactérias consomem tanto oxigênio que a vida para qualquer outro ser que viva nas partes profundas do oceano torna-se impossível. De acordo com a última estimativa, em torno de 400 'zonas mortas' pelo mundo sufocam formas de vida majoritárias no oceano [...] essas 'zonas mortas' não estão, entretanto, mortas. Na verdade, elas estão repletas de vida - apenas não aquela que 'nós' queremos" (SCHRADER, 2008b. s/p).
}

Vol. 03, N. 11, Jul. - Set., 2020 - http://periodicoscientificos.ufmt.br/ojs/index.php/rebeh/index 
possa ser capturada em sua totalidade. Portanto, parte do dilema que produz a controvérsia, eu sugiro, é que as questões "quem são as Pfisteria piscicida" e “o que as Pfiesteria tóxicas fazem” estão inseparavelmente emaranhadas. [...]

As Pfiesteria cultivadas exclusivamente com presas de algas não conseguem matar peixes. Ironicamente, elas precisam dos peixes para se tornarem suas assassinas. As Pfiesteria tóxicas apenas "são" tóxicas na relação com peixes e em condições ambientais específicas. Em termos mais simples: SEM PEIXE NÃO HÁ MATADORA DE PEIXE. Se você quiser saber quem são as Pfiesteria em si - como se isso fosse possível - você inevitavelmente produzirá Pfiesteria não tóxica, mas não Pfiesteria piscicida, a assassina de peixes (SCHRADER, 2010, p. 283-285).

Como nossas colaboradoras queer, os mundos em performance de Pfiesteria não são localizáveis no espaço ou no tempo. Examinando uma gama de abordagens laboratoriais para estudar a toxicidade e o status de espécie de Pfiesteria, Schrader aponta que abordagens que insistem em um modelo simplista de "emissor-transmissor-receptor" falham em estabelecer a toxicidade de Pfiesteria porque seus procedimentos - que incorporam modos particulares de se definir toxicidade e entendimentos particularmente rudimentares de causalidade e temporalidade - impedem, por pressuposto, os tipos de performances agenciais tóxicas nas quais Pfiesteria se engaja.

Em contrapartida, o procedimento desenhado em laboratório por Burkholder e colaboradores não suprime a agência material de Pfiesteria ao tentar impor um modelo determinista de causa como o mecanismo de morte dos peixes. Em vez disso, a abordagem deles permite que Pfiesteria se engaje em relações causais não-deterministas e temporais heterogêneas.

[As] definições agenciais [usadas no laboratório por Burkholder] não pressupõem a toxicidade como propriedade inerente de um estágio de vida particular. Na verdade, as diversas culturas tóxicas de Pfiesteria referem-se a performances de um agenciamento de formas, descritas como manifestações temporais de um ciclo de vida variável que não pode ser isolado das intra-ações das quais emerge. Já que as culturas não são categorias fixas, mas podem transformar-se umas nas outras, seu tipo de toxicidade não pode simplesmente ser controlada pelos parâmetros ambientais atuais; depende, pois, da história de vida de Pfiesteria. Em outras palavras, a toxicidade depende dos efeitos da intra-ação indeterminável que levou Pfiesteria a seu estado atual. Os dinoflagelados agem de maneira diferencial em relação aos peixes dependendo de quão recentemente eles tiveram contato com peixes. Nos termos de Burkholder, Pfiesteria têm uma memória bioquímica para estimulação recente por peixes vivos, o que introduz uma dimensão temporal variável na relação entre organismos e seus ambientes [Retirado de uma versão inicial e não publicada de Schrader (2010)] 
Por essa razão, o que Schrader demonstra é que práticas laboratoriais responsáveis devem considerar as performances agenciais do organismo ao tornar evidente a natureza específica das relações causais. Responsabilidade/Responsividade envolve oferecer oportunidades para que o organismo responda. Dinoflagelados não respondem a modelos deterministas de causalidade. Eles insistem que suas performances agenciais sejam levadas em conta. Porém, uma abordagem performativa das práticas científicas não será simplesmente suficiente. Entender que os objetos de investigação são efeitos antes que causas não resolve de uma vez por todas a matéria da causa como sendo de acausalidade ou não tendo nenhuma relação causal no espaço, esvaziando o determinismo. Em outras palavras, não se trata simplesmente de escolher entre "causalidade", "acausalidade" ou "não causalidade". O que as Pfiesteria tornam evidente é como a causalidade torna-se intra-atividade iterativa (BARAD, 2007). De certo, é o fato da causalidade como intra-atividade iterável se tornar, portanto, uma herança que temporaliza o fenômeno em traços mortais 'cortados juntos' e depender da inclusão de preocupações específicas como parte do referente experimental, que torna o experimento repetível e evidencia a inseparabilidade de questões de epistemologia e ética (SCHRADER, 2010). A prática científica responsável/responsiva é simultaneamente uma questão de boas práticas científicas (ciência epistemologicamente sólida) e de justiça-porvir.

\section{A performatividade queer do átomo}

"Ninguém entende esse negócio de quantum queer", afirma Alan Grometstein em The Root of Things (GROMETSTEIN, 1999, p. 4). O que poderia ser mais queer do que um átomo? E por queer não quero dizer apenas estranho. A natureza do "ser átomo", sua identidade, é indeterminação em si mesma ${ }^{51}$.

\footnotetext{
${ }^{51}$ O teórico queer David Halperin (1997, p. 112-113) escreve: “a política queer (...) sua eficácia e sua vida política produtiva podem certamente ser renovadas e estendidas. O primeiro passo nesse procedimento será tentar preservar a função da identidade queer como um lugar vazio, para uma identidade que ainda está em formação e que está por ser realizada. Será conceituar identidade queer como uma identidade em estado de devir mais do que como uma referência para uma forma de vida existente. A política queer, se é para permanecer queer, precisa ser capaz de realizar a função de esvaziar a queeridade de sua referencialidade ou positividade, resguardando-se de sua tendência à corporificação concreta, portanto preservando a queeridade como uma relação resistente antes que uma substância oposicional". Como especificado aqui, a temporalidade queer é aquela de uma abertura futura. Criaturas queer vão um passo além: a "natureza"
}

Vol. 03, N. 11, Jul. - Set., 2020 - http://periodicoscientificos.ufmt.br/ojs/index.php/rebeh/index 
Parecia haver algo queer sobre o quantum desde o começo. Ou melhor, tornouse evidente desde o começo que o quantum causa problemas para a própria noção de "desde o começo"52. Mais de uma década antes do estabelecimento da teoria quântica, o físico Niels Bohr fez o movimento teórico-imaginativo de aplicar a ideia de quantização de energia de Max Planck à matéria em si mesma, e em particular, a cada parte da matéria, isto é, a cada átomo. $\mathrm{O}$ modelo atômico de Bohr é uma variante quântica do modelo atômico do sistema solar proposto por Ernst Rutherford. No modelo de Bohr, cada átomo tem um núcleo (feito de prótons e nêutrons) com elétrons residindo em "orbitais" discretos $^{53}$ (quantizados) em torno do núcleo. Cada elétron em um átomo ocupa um dentre um número finito de níveis de energia discretos. Quando um elétron "salta" de um nível de energia mais alto para um nível de energia mais baixo, um fóton (um quantum de luz) é emitido com uma frequência ("cor") correspondente à diferença de energia entre os dois níveis ${ }^{54}$. Já que cada tipo de átomo na tabela periódica tem uma configuração única de orbitais discretos, o espectro atômico singularmente identifica o átomo que o produz, tal como uma impressão digital atômica ${ }^{55}$.

O modelo de Bohr conseguiu dar conta da estabilidade da matéria e previu acuradamente o espectro de emissão do hidrogênio. O sucesso estrondoso desse modelo garantiu a Bohr o prêmio Nobel em Física. Entretanto, sob cuidadosa análise, torna-se evidente que há algo inerentemente queer à natureza da matéria.

indeterminada da Natureza não só tem um futuro aberto, mas também um passado aberto (ver especificamente a seção deste ensaio sobre o apagador quântico). Certamente, "passado" e "futuro" estão eles mesmos sujeitos à indeterminação.

${ }^{52}$ A maior parte da discussão sobre causalidade quântica cita as desigualdades de Bell (1964) como o exemplo por excelência. Entretanto, a natureza paradoxal da causalidade quântica já é evidente na própria noção de "salto quântico", que é a característica central do modelo atômico de Bohr (1913), o primeiro modelo quântico do átomo (e que precedeu a mecânica quântica).

53 Nota da revisão: variáveis discretas, em estatística, são aquelas cujos resultados são finitos ou enumeráveis.

${ }^{54} \mathrm{O}$ fato de a diferença de energia entre os dois níveis ser emitida como um fóton é resultado da conservação de energia - energia não é criada ou destruída. A conservação da energia (ou da massa-energia de acordo com a teoria da relatividade) é considerada uma lei fundamental da natureza, talvez a lei fundamental da natureza.

55 Imagens valem, de fato mil, palavras aqui. Para abordar um caso concreto, o espectro de emissão do hidrogênio tem quatro linhas primárias: vermelho, azul claro, azul escuro e violeta. É, portanto, possível identificar que elementos estão presentes em um gás incandescente (mesmo a uma grande distância, como uma estrela) ao olhar para seu espectro atômico e ver que cores estão presentes.

Vol. 03, N. 11, Jul. - Set., 2020 - http://periodicoscientificos.ufmt.br/ojs/index.php/rebeh/index 
Considere o processo pelo qual uma única linha de emissão no espectro atômico é produzida. Cada linha espectral (de uma dada cor ou frequência) é resultado de um elétron fazendo um "salto" de um nível de energia mais alto para um nível de energia mais baixo. Qual é a natureza precisa desse "salto"? A expressão "salto quântico" tornouse parte da nossa fala cotidiana, associada ao significado de uma grande mudança, quando, na verdade, a mudança da qual estamos falando não poderia ser se não um menor. "Quantum”, no sentido usado pelos físicos, significa a "menor porção de uma quantidade física que pode existir e em cujos múltiplos ela possa variar" ${ }^{\circ 6}$.

Portanto, um salto quântico é bem pequeno, mas essa não é sua assinatura. O que é mais singular sobre ele é que, diferente de qualquer experiência ordinária de saltar, quando um elétron faz um "salto quântico" isso ocorre de maneira descontínua (enganando a própria noção de "salto"): em particular, o elétron está inicialmente em um nível de energia e então em outro sem que tenha estado em qualquer lugar entre eles! Um salto quântico é um movimento descontínuo. Fenômenos quânticos são famosos por sua excentricidade. Porém, em toda a fanfarra e exibição de uma gama crescente de fenômenos assombrosamente estranhos e toda a maquinaria matemática sofisticada usada para descrevê-los, o ponto crucial desses paradoxos está lá na descontinuidade quântica.

Vamos considerar a situação de perto. Inicialmente, o elétron está em um nível de energia mais alto $E_{2}$; finalmente, ele está em um nível de energia mais baixo $E_{1}$. Em que ponto o fóton é emitido? De acordo com o modelo da física clássica proposto por Rutherford, um elétron atômico continuamente perde energia ao orbitar o núcleo, um espectro contínuo de luz é emitido e o átomo rapidamente decai em um lampejo de luz (por exemplo, átomos são instáveis nesse modelo, o que é uma de suas fraquezas). Por contraste, o modelo quântico de Bohr tem duas características importantes que divergem do modelo clássico: (1) elétrons atômicos não orbitam o núcleo como planetas ao redor do Sol; cada um deve ocupar um entre um conjunto de níveis de energia discretos de cada vez , já que cada "orbital” corresponde a uma energia fixa e os elétrons que residem em um dado orbital não emitem energia (luz), (2) quando elétrons fazem a transição de um nível de energia mais alto para um mais baixo, a energia excedente é emitida em um

\footnotetext{
56 “Quantum, n. 5”, OED Online. Disponível em: http://dictionary.oed.com/cgi/entry/50194299. Nota da tradução: sem data de acesso no original.
}

Vol. 03, N. 11, Jul. - Set., 2020 - http://periodicoscientificos.ufmt.br/ojs/index.php/rebeh/index 
pacote discreto chamado "fóton". Nesse sentido, uma transição contínua entre níveis de energia não é possível. Todavia, agora um problema surge. Se um fóton só pode resultar do salto em si, em que ponto durante esse salto o fóton é emitido (relembre que um fóton é um quantum de luz, portanto, a luz não é emitida continuamente, mas em uma quantidade discreta como partícula de luz)? A emissão do fóton não pode acontecer quando o elétron está no seu caminho de $\mathrm{E}_{2}$ para $\mathrm{E}_{1}$ porque o elétron nunca está em lugar algum entre os dois níveis de energia; tampouco o fóton pode ser emitido quando o elétron está no nível de energia $\mathrm{E}_{1}$ ou $\mathrm{E}_{2}$ porque nenhuma mudança energética (ainda) aconteceu. Além disso, algo parece impróprio quanto à natureza da causalidade, já que se o átomo emitisse um fóton de uma determinada cor enquanto sai de $E_{2}$ (a caminho de $E_{1}$ ), ele já teria que estar onde estava indo $\left(E_{1}\right)$ antes de sair, logo a frequência adequada seria emitida para conservar energia - estranha causalidade! Sendo assim, a natureza paradoxal da causalidade quântica deriva da descontinuidade quântica - o próprio fato de existir uma descontinuidade inerente (constitutiva de todas as intra-ações).

O que constitui a descontinuidade quântica? Tal descontinuidade, que queeriza nossas suposições de continuidade, não é o oposto da continuidade, nem contínua com ela. "Saltos" quânticos não são meros deslocamentos no espaço através do tempo, não daqui-agora para lá-depois, não são quando a ruptura em si que ajuda a constituir os "aquis" e "agoras" e não de uma vez por todas. O ponto não é meramente que algo está aqui-agora e então lá-depois sem nunca ter estado em qualquer lugar entre eles - isso já é desconfortável por si só - mas que o aqui-agora e o lá-depois tornaram-se desajustados: não há um dado lugar ou tempo para eles estarem. Onde e quando os saltos quânticos acontecem? Se a natureza da causalidade é perturbada a tal ponto que o efeito não segue simplesmente à causa em um desdobramento da existência ao longo do tempo, como é possível orientar-se no espaço ou no tempo? Podemos continuar a presumir que o espaço e o tempo ainda estão "aí"?

Essa causalidade queer implica o rompimento da des/continuidade, um rompimento tão desestabilizador e tão estonteante que é difícil acreditar que é isso que contribui para a estabilidade da própria existência. Ou melhor, para dizer de forma um pouco mais precisa, se a natureza indeterminada da existência oscila à beira da estabilidade e da instabilidade, da possibilidade e da impossibilidade, a relacionalidade 
dinâmica entre continuidade e descontinuidade é crucial para o devir sem fim do mundo que resiste tanto à acausalidade quanto ao determinismo.

Eu não quero fazer muito de uma coisa pequena, mas o quantum, essa minúscula disjunção que não existe nem no espaço nem no tempo, torce a própria natureza da relação entre continuidade e descontinuidade ao ponto de a natureza da mudança mudar a cada intra-ação. Mudança, em qualquer caracterização geral, é um dinamismo de tipo inteiramente diferente que funciona de um modo inteiramente diferente do que se presume operar na matéria situada no espaço e no tempo (por exemplo, uma diferença importante é que a existência não é simplesmente um desdobramento do ser que evolui no espaço e no tempo); em vez disso, aquilo que está por tornar-se, e é imediatamente reconfigurado, acarreta devires intra-ativos e iterativos da espaçotempomaterialização ${ }^{57}$. Intra-atividade iterativa configura e reconfigura emaranhamentos. Emaranhamentos não são a interconexão de coisas ou eventos separados no espaço e no tempo. Emaranhamentos são dobras de espaçotempomaterializações.

\section{Identidades queer, apagamentos quânticos e im/possibilidades para a mudança do "passado"}

Emaranhamento quântico é o traço característico da mecânica quântica, aquele que reforça sua inteira saída de linhas clássicas de pensamento. - Erwin Schrödinger (1983, p. 152), The Present Situation in Quantum Mechanics

A preocupação não é com horizontes de presentes - passados ou futuros - modificados, mas com um "passado" que nunca esteve presente, e que nunca estará, cujo futuro por vir nunca será uma produção ou uma reprodução na forma de presença. - Jacques Derrida (1994a, p. 21), Margins of Philosophy

Nós escolhemos examinar um fenômeno que é impossível, absolutamente impossível, de explicar em qualquer modo clássico, e que tem em si o coração da mecânica quântica. Na verdade, ele contém um mistério único.

- Richard Feynman (1994, p. 122), Six Easy Pieces

57 Espaço, tempo e matéria não estão simplesmente "lá"; em vez disso, eles são constituídos (e iterativamente constituídos) através das performances intra-ativas do mundo.

Vol. 03, N. 11, Jul. - Set., 2020 - http://periodicoscientificos.ufmt.br/ojs/index.php/rebeh/index 
Físicos agora afirmam ter evidência empírica de que é possível não só mudar o passado, mas também mudar a própria natureza do ser em si no passado. O experimento em questão é a chamada "experiência do apagador quântico". 58

De acordo com Niels Bohr, a física quântica torna evidente o fato de que entidades (átomos, fótons, elétrons, etc) não possuem uma identidade ontológica inerente (tanto como partículas quanto como ondas, isto é, como objetos localizados ou como perturbações estendidas em um campo) ${ }^{59}$. Na abordagem de Bohr, a identidade não é dada, mas performada. Isso pode ser demonstrado usando um simples equipamento chamado aparelho de dupla fenda, que é basicamente uma tela com dois buracos. De acordo com a física clássica, se você quer saber se uma entidade é uma onda ou uma partícula você simplesmente deve enviá-la através de duas fendas abertas de maneira repetida (ou, alternativamente, enviar muitas entidades idênticas através das fendas), desenvolvendo um padrão ao longo do tempo. Se um padrão de dispersão aparecer com a maioria das entidades pousando diretamente em frente a uma fenda ou à outra, é uma partícula. Se um padrão de difração aparecer, como resultado de alguma perturbação (como a de uma onda aquática), atravessando as duas fendas simultaneamente, é uma onda ${ }^{60}$. Essa diferenciação é importante: um padrão de difração é resultado de uma interferência daquilo que emerge através de múltiplas fendas ao mesmo tempo (ao invés vez de em uma fenda ou na outra como no caso da partícula). Ondas e partículas produzem padrões de dupla-fenda distintos. Logo, do ponto de vista da física clássica, este é um teste definitivo da natureza de uma entidade.

A física quântica põe em questão a classificação ontológica clássica de entidades em dois tipos distintos: ondas e partículas. Experimentos no início do século XX produziram resultados que eram inexplicáveis nos termos das noções clássicas de

\footnotetext{
${ }^{58}$ Somente resumi certas características-chave do experimento. Para uma descrição mais detalhada e análise desse experimento, ver Barad (2007).

${ }^{59} \mathrm{De}$ acordo com a física clássica, tudo no mundo poderia ser definitivamente colocado em uma categoria ou na outra; a natureza de toda entidade (embora a natureza de "entidade" em si esteja em questão) era tal que seria (inerentemente) ou onda ou partícula. Tomo a liberdade de usar a palavra "entidade" já que é isso que está precisamente em questão.

${ }^{60}$ Um padrão de difração é aquele que é produzido por perturbações de interferência de ondas aquáticas quando duas pedras são soltas simultaneamente em uma lagoa. Isto é, trata-se de um padrão de regiões alternativas de intensidade.
}

Vol. 03, N. 11, Jul. - Set., 2020 - http://periodicoscientificos.ufmt.br/ojs/index.php/rebeh/index 
identidade e o experimento da dupla-fenda é suficiente para revelar esses comportamentos não clássicos. Envie um elétron através da dupla-fenda centenas de vezes (ou envie centenas de elétrons através das fendas um de cada vez), e o padrão que emerge é o característico de ondas. O mesmo experimento pode ser feito com átomos ou nêutrons ou fótons, e um padrão de difração é produzido em cada caso. Porém diferente de ondas de água, partículas não "interferem” uma na outra (elas não podem ocupar o mesmo espaço ao mesmo tempo), e em qualquer caso, já que elas estão sendo enviadas através das fendas uma de cada vez, elas não têm a chance de encontrar umas às outras no caminho. Assim, o que é responsável pelo comportamento de onda? Cada partícula deveria passar por uma fenda de cada vez (por definição) e ainda assim o padrão de difração é o resultado de uma entidade (como uma onda aquática) passando pelas duas fendas ao mesmo tempo.

Para ajudar a resolver o paradoxo, suponhamos desenhar um equipamento para “olhar e identificar" o que está ocorrendo nas fendas, para "assistir" enquanto cada elétron passa pelas fendas em seu caminho até a tela. Na verdade, Einstein, que rejeitava a teoria quântica e estava comprometido com uma ontologia clássica, propôs tal equipamento "qual-fenda" para demonstrar que a física quântica era conceitualmente autocontraditória em dizer que a entidade seria revelada como partícula nas fendas (atravessando uma ou a outra) e como onda na tela, afirmando que entidades não podem ser ondas e partículas ao mesmo tempo. Bohr discordou de Einstein e argumentou que o experimento "qual-fenda" de Einstein demonstra graciosamente a sua ideia de complementaridade, segundo a qual uma entidade se comporta ora como onda, ora como partícula, dependendo de como ela é mensurada (isto é, da natureza do aparelho de mensuração com o qual a entidade se emaranha). No caso de um aparelho de dupla-fenda com um detector "qual-fenda", Bohr argumentava que o padrão a ser exibido seria de dispersão, característico do comportamento de partícula. Em outras palavras, embora uma entidade performasse como onda com um experimento dupla-fenda simples (sem detector "qual-fenda"), ele performa como partícula com um aparelho dupla-fenda modificado para incluir um detector "qual-fenda". Portanto, a própria natureza da entidade - sua ontologia - muda (ou melhor, torna-se diferencialmente determinada) dependendo do aparelho experimental usado para determinar sua natureza. Para Bohr, a 
complementaridade salvava a teoria de contradições e permitia resultados objetivos a serem obtidos. Sua explicação é que o referente objetivo para conceitos, tais como "onda" e "partícula", não é um objeto determinadamente delimitado com características inerentes (como a ontologia da física clássica diria), mas o que ele chamou de fenômeno - o emaranhamento/inseparabilidade de "objeto" e "aparelho" (que não pré-existem ao experimento, mas emergem do mesmo). Bohr chegou a esses resultados por uma abordagem muito heterodoxa para um físico - ele focou sua atenção em como os conceitos funcionam (um passo radicalmente raro para um cientista!), em como eles fazem o trabalho que fazem e em como eles vêm a significar aquilo que significam ${ }^{61}$.

O experimento de dupla fenda foi foco de debate acalorado e de discussões infinitas pelos fundadores da física quântica no início da década de 1920 e continua a ser um tema de grande interesse até os dias atuais. Era o experimento gedanken (de pensamento) de seu tempo. Einstein e Bohr discutiram infinitamente sobre isso. Hoje, o experimento que nunca viria a existir (só poderia existir no reino rarefeito do puro pensamento) pôde, de fato, ser realizado em laboratório: bem-vinda ao mundo da (meta)física experimental!

Sem abordar muitos detalhes do experimento, é suficiente dizer que podemos desenhar um equipamento de dupla-fenda muito inteligente com um detector "qualfenda" (composto por um laser e duas cavidades). Este aparelho executa a medição da fenda sem perturbar o "movimento externo" do átomo, manipulando apenas as "partes internas" dele. O átomo, enquanto caminha para as fendas duplas, passa através de um feixe de laser, excitando, assim, um de seus elétrons para um nível de energia mais alto. Duas “cavidades de micromaser" são configuradas em cada fenda, projetadas para forçar esse elétron a "pular" de volta para o nível mais baixo de energia à medida que o átomo passa pela cavidade, emitindo um fóton de "revelação", que é deixado na cavidade marcando por qual fenda o elétron passou no seu caminho até a tela.

Dirigir o experimento sem o detector qual-fenda revela o padrão de difração - isto é, átomos comportando-se como ondas. Se o experimento ocorre novamente com o

${ }^{61}$ Ver Barad (2007) para mais detalhes.

Vol. 03, N. 11, Jul. - Set., 2020 - http://periodicoscientificos.ufmt.br/ojs/index.php/rebeh/index 
detector qual-fenda, o padrão é o de partículas, assim como Bohr previu. Esta é uma evidência empírica direta de que a identidade não é fixa e inerente, mas performativa.

Bohr explicou a natureza performativa das coisas em termos de emaranhamentos quânticos do aparelho de mensuração e do objeto a ser mensurado: de acordo com Bohr, não se trata das coisas comportarem-se de modos distintos quando medidas diferentemente. Ao invés disso, o ponto é que só existe o fenômeno - a intra-ação do "aparelho" e do "objeto" em sua inseparabilidade. Agora, se a hipótese de Bohr de que fenômenos são emaranhamentos quânticos prevalece, algumas coisas evidentemente impossíveis tornam-se possíveis. Suponha que o detector "qual-fenda" seja feito de tal modo que a evidência de qual fenda a entidade em questão (neste caso, um átomo) cruza possa ser apagada após a passagem pelas fendas ${ }^{62}$. Acontece que se a informação "qualfenda" é "apagada", novamente um padrão de difração característico de ondas fica em evidência (como no caso da ausência de um detector "qual-fenda"). Na verdade, não importa em que ponto a informação é apagada - em particular, ela poderia ser apagada depois que a entidade em questão já houvesse passado através do aparelho inteiro e feito sua contribuição para o padrão. Em outras palavras, se uma entidade pode ou não atravessar o aparelho como uma onda ou como partícula - através das suas fendas simultaneamente ou uma fenda ou outra, respectivamente - pode ser determinado posteriormente - após ela já ter passado pelo aparelho. Isto é, não é simplesmente o comportamento passado de uma dada entidade que foi mudado por algo que acontece no futuro, mas a própria identidade da entidade foi mudada. Assim, temos evidência empírica do fato da identidade do átomo, sua ontologia, nunca é fixa, mas sempre aberta a reconfigurações do futuro e do passado!

Os físicos que propuseram a experiência do apagador quântico interpretam esses resultados como a possibilidade de "mudar o passado". A linguagem que eles usam fala de uma leitura particular desses resultados que não combina com a física filosófica de Bohr: em particular, eles se referem à informação "qual-fenda" como tendo sido “apagada" (por essa razão o nome de experiência é "apagador quântico") e ao padrão de difração como tendo sido "recuperado" (como se o padrão original houvesse retornado).

${ }^{62}$ Para detalhes de como fazer tal detector, ver Barad (2007). 
Entretanto, como argumentei, essa interpretação não é tão cuidadosa quanto poderia, além de ser baseada em suposições que estão sendo colocadas em questão pelo próprio experimento, suposições acerca da natureza do ser e do tempo.

Caso a metafísica da presença seja assumida, segundo a qual o padrão resulta do comportamento de um grupo de objetos individualmente determinados, parece inexplicável que o "apagamento" da informação sobre qual fenda cada entidade individual atravessou, depois que os indivíduos atravessaram as fendas, poderia ter qualquer efeito. Do contrário, que noção de causalidade poderia dar conta de tão estranha ocorrência? Qual poderia ser a fonte de tal comunicação instantânea, um tipo de conspiração global de atores individuais agindo em conjunto? Que tipo de causalidade assustadora de ação à distância é essa?! A dificuldade, aqui, é a suposição equivocada de uma ontologia clássica baseada na crença em um mundo povoado por coisas existentes independentemente, com limites e propriedades determinados, que se movem em um contêiner chamado "espaço", seguindo uma sequência linear de momentos chamada "tempo". Porém, as evidências indicam que o mundo não opera de acordo com tal ontologia clássica.

Argumentei em outro lugar (BARAD, 2007) que ao ler difrativamente insights de físicos e teóricos pós-estruturalistas uns através dos outros é possível “estender" e elaborar mais profundamente as ideias da teoria de performatividade de Butler além do escopo do humano (de que se deve fazer isso para abordar o humano mesmo em sua materialidade), se certas noções-chave como materialidade, discursividade, agência e causalidade forem finamente revisadas à luz da revisão radical de entendimentos clássicos da matéria e da produção de sentidos sugeridas por esses resultados. Examinar a evidência do apagador quântico à luz desse entendimento performativo pós-humanista da natureza da natureza resolve alguns dos evidentes paradoxos e confere ao desconstrucionismo força empírica. Para colocar o ponto de outra forma, esse movimento realiza uma aposta de que as reverberações radicais do desconstrucionismo não são apenas imaginações perversas da mente ou da cultura humana, mas são, de fato, acontecimentos queer do mundo ${ }^{63}$.

\footnotetext{
${ }^{63}$ Kirby (2011) argumenta por essa perspectiva e oferece evidências convincentes de que a história pode ser contada de dentro da teoria da desconstrução.
}

Vol. 03, N. 11, Jul. - Set., 2020 - http://periodicoscientificos.ufmt.br/ojs/index.php/rebeh/index 
Ao retornar à evidência em questão, a experiência do "apagador" quântico confere peso empírico à afirmação desconstrucionista de que a preocupação "não é com horizontes de presentes - passados ou futuros - modificados, mas com um 'passado' que nunca esteve presente e que nunca estará, cujo futuro por vir nunca será uma produção ou uma reprodução na forma de presença" (DERRIDA, 1994a, p. 21). A evidência é, de fato, consistente com esse ponto de que não é que (ao apagar a informação depois do fato de) o experimento mude um passado que já esteve presente. Na verdade, o ponto é que o passado nunca esteve simplesmente lá para começar e o futuro não é simplesmente o que se desdobrará; o "passado" e o "futuro" são iterativamente retrabalhados e dobrados através das práticas iterativas de espaçotempomaterialização - incluindo a detecção "qual-fenda" e o subsequente apagamento de sua informação -; são todos um fenômeno. Espaço e tempo são fenomenais, isto é, eles são intra-ativamente produzidos no fazerfenômeno; nem espaço nem tempo existem como um dado determinado fora dos fenômenos ${ }^{64}$.

Como eu mencionei, a evidência é contra a afirmação feita por alguns físicos de que todo traço do evento é "apagado" quando a informação "qual-fenda" é destruída e o padrão de difração prévio é "recuperado". Contrariamente, o padrão de difração produzido como um resultado do apagamento local de informação (como a de qual fenda o átomo atravessou) não é o mesmo do "original" (isto é, como se fosse o padrão de difração produzido antes que a mensuração "qual-fenda" fosse feita). Diferente do original, o novo padrão de difração não está plenamente evidente sem traçar explicitamente os emaranhamentos (existentes). $O$ traço de todas as mensurações permanece mesmo quando a informação é apagada; toma trabalho fazer os emaranhamentos fantasmáticos visíveis. O passado não é fechado (nunca foi), mas o apagamento (de todos os traços) não é o que está em jogo. O passado não é o presente. "Passado" e "futuro" são iterativamente reconfigurados e dobrados através da intraatividade em curso do mundo. Não há relação inerentemente determinada entre passado e futuro. Fenômenos não são localizados no espaço e no tempo. Na verdade, fenômenos são emaranhamentos materiais dobrados e ligados pela espaçotempomaterialização do

\footnotetext{
${ }^{64}$ Ver também Barad (2010).
}

Vol. 03, N. 11, Jul. - Set., 2020 - http://periodicoscientificos.ufmt.br/ojs/index.php/rebeh/index 
universo. Mesmo o "retorno" do padrão de difração não sinaliza um voltar, um apagamento da memória, a restauração de um passado presente. A memória - o padrão de dobras sedimentadas da intra-atividade iterativa - está escrita na fabricação do mundo. O mundo "guarda" a memória de todos os traços; ou melhor, o mundo é sua memória (materialização dobrada).

\section{Conclusões}

Minhas colaboradoras e eu apresentamos uma série de desafios à ontologia clássica - uma visão de mundo que postula a existência de entidades discretas que interagem umas com as outras em um estilo causal localmente determinado, no qual mudança é o resultado de um evento (a causa) causando outro evento (o efeito) e causas efetuam a mobilização de entidades movendo-se através do espaço de acordo com um fluxo linear de tempo. As suposições que suportam essa visão incluem as seguintes: o mundo é composto por objetos individuais com propriedades e fronteiras determinadas, o espaço é um dado volume no qual eventos ocorrem, tempo é um parâmetro que avança de modo linear e efeitos sucedem suas causas. Todas essas suposições foram postas em questão pelas performances queer da natureza: raios, células neurorreceptoras em arraias, uma forma de vida animal-planta dinoflagelada encontrada em estuários da América do Norte, átomos, e humanos estão entre as criaturas da natureza cujas práticas, identidades e estatuto de espécie não podem ser propriamente nuançadas em uma ontologia clássica.

Vimos, por exemplo, como conceitos clássicos de causalidade e identidade falham em cada caso e como suas habilidades comunicativas pouco usuais, suas relações causais queer, são inexplicáveis se suas identidades são entendidas em termos de entidades existentes independentemente. Essas criaturas não podem ser entendidas como agentes discretos interagindo com um ambiente ou com outros agentes externos ou separados, não quando a sucessão presumida de efeito seguido de causa é desencaixada e a causalidade parece assumir algum tipo de caráter não clássico. Cada uma das criaturas que consideramos não apenas "desafia nossa concepção de tempo como [um] fluxo homogêneo de momentos auto-idênticos, nos quais uma causa por definição precede seu efeito" (SCHRADER, 2010, p. 278-279), mas também a própria noção de identidade “e 
seus derivados, incluindo questões de causalidade, responsabilidade/responsividade e considerabilidade.

Em seu lugar, propus uma ontologia realista agencial ou o que se poderia chamar de "ontologia quântica", baseada na existência de fenômenos em vez de coisas existentes independentemente (BARAD, 2007). Esses emaranhamentos performativamente materializantes da espaçotempomaterialização são capazes de perceber as performances causalmente complexas que consideramos aqui.

Por outa via, repetidamente enfatizei que a mudança ontológica sugerida por esses resultados não está necessariamente circunscrita à escala microscópica ${ }^{65}$. Porém, de alguma forma, minha repetição exaustiva e o aprofundamento desse ponto não evitam as tentativas amedrontadas de conter, domesticar ou normalizar a queeridade da natureza, que não fica em quarentena e está sempre ameaçando vazar e contaminar a "vida como a conhecemos" -, transformando a casa de diversões e a aberração perversa das travessuras atômicas em uma "catástrofe" em larga escala indutora de ansiedades. Minha esperança é que ao examinar esses exemplos envolvendo entidades macroscópicas, tais como as performances ontológicas queer-quânticas de Pfiesteria e do raio, a queeridade intersticial da natureza possa ser apreciada por entre as divisões de escala e de familiaridade. Por exemplo, embora um fenômeno macroscópico cotidiano, como os raios, possa ter algumas de suas características explicadas pelas leis da física clássica, ele exibe alguns tipos de comportamento queer que átomos fazem num domínio microscópico. Diferente de fenômenos mais "exóticos", menos familiares, como os dos átomos, cujos comportamentos queer se recusam a ser civilizados por leis da física clássica, esse fenômeno macroscópico cotidiano apresenta um conjunto de dilemas, exibindo uma série de acontecimentos queer/quânticos, de dentro do domínio da física "clássica”. Que

\footnotetext{
${ }^{65}$ Há dois problemas distintos aqui. Um é de como entidades e eventos são entendidos. Essas são questões ontológicas. Um problema separado é saber se o comportamento da entidade em questão pode ser levado em conta em termos das leis da física clássica ou da física quântica (ou de algum outro conjunto de leis ou padrões de engajamento). Certamente, pode-se considerar o raio, por exemplo, como um fenômeno (no sentido técnico da ontologia quântica proposta aqui) e ainda ser capaz de explicar certas características regulares de seu comportamento usando as leis da física clássica. Além disso, curiosamente, aqueles que desafiam a importância da ontologia quântica para o domínio macroscópico rapidamente assumem que ela se aplica inquestionavelmente a domínios submicroscópicos até as menores escalas. Ademais, como argumento em Barad (2007), escala também não é um conceito direto e noções de "macro" e "micro", assim como de "passado" e "futuro", não são ordenadas de maneiras simples.
}

Vol. 03, N. 11, Jul. - Set., 2020 - http://periodicoscientificos.ufmt.br/ojs/index.php/rebeh/index 
indefinições enrustidas podem estar à espreita na classificação supostamente direta de micro e macro?

Comportando-se como um elétron ou como um fantasma, a desconstrução cava seu caminho para dentro e para fora deste ensaio implícita ou explicitamente em cada seção. Junto com Kirby e Schrader, abro espaço às ideias de Derrida a fim de engajar-me verdadeiramente com essas criaturas queer ${ }^{66}$. Sem me aprofundar nesses elementos desconstrutivos mais do que este ensaio permitiria, pode parecer surpreendente ou mesmo desconcertante que mencione a possibilidade de suporte empírico a ideias desconstrutivas como différance. Enquanto a sugestão de que a desconstrução possa ter suporte empírico, talvez, soe como blasfêmia para alguns (especialmente dado o des/entendimento comum de que a desconstrução desconstruiu completamente o empirismo e colocou-o em sono profundo, por assim dizer), nós insistimos em leituras materialistas da desconstrução que abram o empírico e o trabalhe de modo a desatá-lo de entendimentos convencionais e a não presumir que ele possa ser (ou deva ser) colocado em sono profundo. De acordo com minha abordagem realista agencial, afirmações empíricas não são completamente descartadas, mas são entendidas como articulações particulares inteligíveis do mundo (com o devido respeito a todas as várias qualificações necessárias para dar sentido a esta reivindicação). Em particular, afirmações empíricas não fazem referência a entidades individualmente existentes e determinadas, mas a fenômenos-em-seu-devir, onde o devir não está ligado a uma temporalidade futura, mas a relacionalidade radicalmente aberta da própria mundificação do mundo.

Neste breve roçar com o desconstrucionismo, é importante manter em mente que o realismo agencial não é uma leitura direta da física, por assim dizer, mas uma investigação difrativa de diferenças que chegam à matéria, onde insights da física e das teorias pós-estruturalistas e desconstrutivistas foram lidos uns através dos outros ${ }^{67}$.

\footnotetext{
${ }^{66}$ Ver especialmente Kirby (2011); Schrader (2010); Barad (2010). Barad (2010) pode ser lido muito utilmente como um trabalho companheiro deste ensaio.

${ }^{67}$ Sobre difração como metodologia e como fenômeno físico, ver especialmente o capítulo 2 de Barad (2007). Minha noção de difração em uma veia metodológica, em oposição à reflexão, tem uma dívida com Haraway (1997). Difração como metodologia é diferente da crítica construtivista social. Particularmente, a difração não presume uma posição fora da ciência, mas, por sua vez, engaja-se construtivamente e desconstrutivamente com a ciência por dentro (não acriticamente, mas não como crítica). Ontologia, epistemologia e ética, assim como metodologia, estão em questão aqui.
}

Vol. 03, N. 11, Jul. - Set., 2020 - http://periodicoscientificos.ufmt.br/ojs/index.php/rebeh/index 
Como apontei antes, a física desconstrói a si mesma, reabrindo e reconfigurando problemas fundacionais como agência, causalidade, espaço, tempo, matéria e responsabilidade/responsividade conforme se desenvolve ${ }^{68}$.

Eu agora quero retornar às questões suscitadas no início, ou melhor, elas retornam, aqui, na medida em que atravessam todo este ensaio. Quero delinear algumas questões éticas centrais e preocupações entrelaçadas ao longo da discussão de causalidade, temporalidade e emaranhamento quando informados por encenações performativas queer dessas criaturas não humanas.

As noções derridianas de "justiça por vir" e de différance assombram este ensaio por bons motivos. Na minha abordagem realista agencial, diferenciação não é meramente cortar separado, mas também cortar junto em um mesmo movimento: cortar juntoseparado. Diferenciação é matéria de emaranhamento! Emaranhamentos não são entrelaçamentos de entidades separadas, mas relações irredutíveis de responsabilidade/responsividade. Não há uma linha divisória fixa entre "eu” e o "outro", "passado" e "presente" e "futuro", "aqui" e "agora", "causa" e "efeito". Des/continuidade quântica não é uma disjunção ordinária. Cortes agenciais não marcam uma separação absoluta, mas um corte junto/separado - uma "conjunção dos disparatados (...) sem ferir a disjunção, a dispersão, ou a diferença, sem apagar a heterogeneidade do outro (...) sem ou antes da junção sintética de conjunção e disjunção" (DERRIDA, 1994b, p. 29). Cortes agenciais - intra-ações - não produzem separação (absoluta), eles se engajam em separabilidade agencial - diferenciação e emaranhamento (este é um único movimento, não são processos sucessivos). Cortes agenciais retrabalham radicalmente relações de junção e disjunção. Separabilidade agencial, nesse sentido, é uma questão de heterogeneidade irredutível que não é subsumida por relações de herança e mantém ligados os disparatados sem reduzir a diferença à mesmidade.

A descontinuidade quântica queeriza a própria noção de diferenciação. Ela oferece uma interrogação muito necessária sobre considerar, levar em consideração e considerabilidade que não é derivada de uma noção fixa de identidade ou mesmo de um intervalo ou origem fixa. Considerar - levar em conta o que se materializa e o que é

\footnotetext{
${ }^{68}$ Isso invoca o argumento de Derrida (1985) de que a desconstrução não é um método, mas aquilo que os textos fazem.
}

Vol. 03, N. 11, Jul. - Set., 2020 - http://periodicoscientificos.ufmt.br/ojs/index.php/rebeh/index 
excluído da materialização - não pode ser um cálculo direto, já que não pode ser baseado em uma existência pressuposta de entidades individuais que podem ser adicionadas a, subtraídas de ou igualadas umas às outras. Considerabilidade não pode ser reduzida a identificar fatores causais individuais e a atribuir culpa a essa ou aquela causa. Certamente, causalidade é uma questão inteiramente queer. Em verdade, considerabilidade é um compromisso ético-onto-epistemológico com entender como diferentes cortes pesam na intra-atividade reiterativa da mundificação, isto é, os emaranhamentos da espaçotempomaterialização. Levar em consideração envolve ser considerável, já que todas as considerações são de dentro, não de fora. Não há posição puramente externa, só separabilidade agencial, diferenças desde dentro, différance. Considerabilidade não pode ser baseada na matemática da identidade. Substituições simples, relações de equivalência ou transitividades entre elementos individuais são desfeitas.

Ironicamente, em um sentido importante, não há "atos contra a natureza", não se eles envolvem o sentido de exterioridade absoluta usualmente suposto. Nessa reconfiguração radical de natureza/cultura, não há fora da natureza a partir do qual podemos agir; só há "atos de natureza" (incluindo pensamento e linguagem), que não são reduzir cultura a natureza, mas rejeitar a noção de que natureza é inerentemente inadequada e particularmente vazia de significado e de valor, portanto requerente da cultura como seu suplemento (KIRBY, 2011). E se entendêssemos cultura como algo que a natureza faz ${ }^{69}$ ? Essa reconfiguração dos binários natureza/cultura e de humano/não humano dá espaço para ultraje moral direcionado a atos específicos de violência contra humanos e não humanos, incluindo os efeitos materiais(lizantes) de como eles são diferenciados (e, assim, equacionados).

Emaranhamentos não são um nome para a interconexão de todos os seres como uma coisa só, mas para as relações materiais específicas da diferenciação em curso do mundo. Emaranhamentos são relações de obrigação com - estar ligado aos outros - traços

\footnotetext{
${ }^{69}$ Bohr argumenta que "nós [humanos] somos parte da natureza que buscamos entender" como uma inspiração primária para essa física filosófica. Kirby tem implacavelmente interrogado a divisão natureza/cultura e insistido nesses pontos através de todo o seu trabalho. Ela faz a provocação de que a afirmação controversa de Derrida de que "não existe fora do texto" deveria ser entendida como "não existe fora da natureza" (KIRBY, 2011).
}

Vol. 03, N. 11, Jul. - Set., 2020 - http://periodicoscientificos.ufmt.br/ojs/index.php/rebeh/index 
dobrados de outridade. Outrificação, a constituição do "Outro", envolve uma dívida ao "Outro", que está ligada irredutivelmente e materialmente atravessada ao "eu" - uma difração/dispersão da identidade. "Outridade" é uma relação emaranhada de diferença (différance).

Uma ética do emaranhamento envolve possibilidades e obrigações para/com refigurar os efeitos materiais do passado e do futuro. Não há redenção absoluta, mas o espaçotempomatéria pode ser produtivamente reconfigurado, remexendo $\mathrm{im} /$ possibilidades no processo. Mudanças ao passado não apagam marcas corporais; os efeitos materiais sedimentares dessas próprias reconfigurações - memórias/lembranças estão escritas na carne do mundo. Nossa dívida com aqueles que já estão mortos e com aqueles que ainda não nasceram não podem ser desentrelaçadas de quem somos. E se reconhecêssemos que a diferenciação é um ato material que não é sobre separação radical, mas, pelo contrário, sobre construir conexões e compromissos? $?^{70}$

\section{Referências}

AGAMBEN, Giorgio. Remnants of Auschwitz: The Witness and the Archive. Nova York: Zone Books, 1999.

AGAMBEN, Giorgio. The Open: Man and Animal. Stanford: Stanford University Press, Stanford.

BAGEMIHL, Bruce. Biological Exuberance: Animal Homosexuality and Natural Diversity. Nova York: Stonewall Inn Editions, 2000.

BARAD, Karen. Posthumanist Performativity: toward an understanding of how matter comes to matter. Signs: Journal of Women in Culture and Society, v. 28, n. 3, p. 801$831,2003$.

BARAD, Karen. Meeting the Universe Halfway: Quantum Physics and the Entanglement of Matter and Meaning. Duke University Press, Durham, 2007.

\footnotetext{
70 Possuo uma dívida com Vicki Kirby e Astrid Schrader pela inspiração de seus trabalhos e pela generosidade em me permitir convidar alguns de seus colaboradores não humanos favoritos, pegar emprestadas citações volumosas de seus trabalhos e incluir citações de textos não publicados para este ensaio. Sou, entretanto, a única responsável por qualquer erro ou colocação equivocada neste texto. Sou também muito grata a Fern Feldman por sua leitura paciente deste ensaio e por suas sugestões e comentários muito importantes.
}

Vol. 03, N. 11, Jul. - Set., 2020 - http://periodicoscientificos.ufmt.br/ojs/index.php/rebeh/index 
BARAD, Karen. Quantum Entanglements and Hauntological Relations of Inheritance: Dis/continuities, SpaceTime Enfoldings, and Justice-to-Come. Derrida Today, v. 3, n. 2, p. 240-268, 2010.

BARAD, Karen. Performatividade pós-humanista: para entender como a matéria chega à matéria. Revista Vazantes, v. 1, n. 1, p. 7-34, 2017.

BELL, John S. On the Einstein Podolsky Rosen paradox. Physics Physique Физика, v. 1, n. 3, p. 195-200, 1964.

BIRKE, Lynda; BRYLDE, Mette; LYKKE, Nina. Animal Performances: an exploration of intersections between feminist science studies and studies of human/animal relationships. Feminist Theory, v. 5, n. 2, p. 167-183, 2004.

BUTLER, Judith. Gender Trouble: Feminism and the Subversion of Identity. Nova York: Routledge, 1990.

BUTLER, Judith. Bodies That Matter: On the Discursive Limits of "Sex". Routledge, New York, 1993.

COATS, D. Wayne. Dinoflagellate life-cycle complexities. Journal of Phycology, v. 38, n. 3, p. 417-419, 2002.

DERRIDA, Jacques. Letter to a Japanese Friend. In: WOOD, David; BERNASCONI, Robert (Orgs.). Derrida and Différance. Warwick: Parousia Press, 1985. p. 71-82.

DERRIDA, Jacques. 'Eating Well' or the Calculation of the Subject: An Interview with Jacques Derrida. In: CADAVA, Eduardo; CONNOR, Peter; NANCY, Jean-Luc (Orgs.). Who Comes After the Subject? Routledge, New York, 1991. p. 96-119.

DERRIDA, Jacques. Margins of Philosophy. Chicago: The University of Chicago Press, 1994a.

DERRIDA, Jacques. Specters of Marx: The State of Debt, the Work of Mourning, and the New International. Nova York: Routledge, 1994b.

DERRIDA, Jacques. The Animal That Therefore I Am. Nova York: Fordham University Press, 2008.

FEYNMAN, Richard. Six easy pieces: Essentials of Physics Explained by its Most Brilliant Teacher. Nova York: Basic Books, 1994.

GIFFNEY, Noreen; HIRD, Myra. (orgs). Queering the Non/human. Nova York: Asghate, 2008. 
GROMETSTEIN, Allan. The Roots of Things: Topics in Quantum Mechanics. Nova York: Kluwer Academic/Plenum Publishers, 1999.

HACKETT, Jeremiah D.; ANDERSON, Donald M.; ERDNER, Deana L.; BHATTACHARYA, Debashish. Dinoflagellates: a remarkable evolutionary experiment. American Journal of Botany, v. 91, n. 10, p. 1523-1534, 2004.

HALPERIN, David. Saint Foucault: Towards a Gay Hagiography. Oxford University Press, Oxford, 1997.

\section{HARAWAY, Donna. Modest_Witness@Second_Millennium.FemaleMan_Meets_}

OncoMouse: Feminism and Technoscience. Routledge, London, 1997.

HARAWAY, Donna. When Species Meet. Minneapolis: University of Minnesota Press, 2008.

KIRBY, Vicki. Telling Flesh: The Substance of the Corporeal. Nova York: Routledge, New York, 1997.

KIRBY, Vicki. Quantum Anthropologies. In: SIMMONS, Laurence; WORTH. Heather. (orgs.). Derrida Downunder. Palmerston: Dunmore Press, 2001.

KIRBY, Vicki. Judith Butler: Live Theory. Nova York: Continuum, 2006.

KIRBY, Vicki. Quantum Anthropologies: Life at Large. Durham: Duke University Press, 2011. p. 53-68.

MAMDANI, Mahmood. When victims become killers: Colonialism, Nativism, and the Genocide in Rwanda. Princeton: Princeton University Press, 2001.

RAFFLES, Hugh. Jews, Lice, and History. Public Culture, v. 19, n. 3, p. 521-566, 2007.

RAFFLES, Hugh. Insectopedia. Nova York: Pantheon Books, 2010.

SCHRÖDINGER, Erwin. The Present Situation in Quantum Mechanics. In: WHEELER, John A; ZUREK, Wojciech. (eds). Quantum Theory and Measurement. Princeton: University Press, Princeton, 1983.

SCHRADER, Astrid. Dinos \& Demons: The Politics of Temporality and Responsibility in Science. Doutorado (História da Consciência) - University of California, Santa Cruz, 2008a. 
SCHRADER, Astrid. Toxic Waters and Turbulent Times: Red Tides, Dinoflagellates, and Phantomatic Species. Versão não publicada de artigo enviado à American Anthropological Association, San Francisco, novembro de 2008b.

SCHRADER, Astrid. Responding to Pfiesteria piscicida (the Fish Killer): phantomatic ontologies, indeterminacy, and responsibility in toxic microbiology. Social Studies of Science, v. 40, n. 2, p. 275-306, 2010.

SEDGWICK, Eve Kosofsky. Queer Performativity: Henry James's the art of the novel. GLQ: A Journal of Lesbian and Gay Studies, v. 1, n. 1, p. 1-16, 1993.

SEDGWICK, Eve Kosofsky. Performativity and Performance. Nova York: Routledge, 1995.

SEDGWICK, Eve Kosofsky. Touching Feeling: Affect, Pedagogy, Performativity. Durham: Duke University Press, 2003.

SPIEGEL, Marjorie. The Dreaded Comparison: Human and Animal Slavery. Nova York: Mirror Books/I.D.E.A., 1997.

SZTYBEL, David. Can the Treatment of Animals Be Compared to the Holocaust? Ethics and The Environment, v. 11, n. 1, p. 97-132, 2006.

UMAN, Martin. Lightning: Physics and Effects. Cambridge: Cambridge University Press, Cambridge, 1986.

WARRICK, Joby. The Feeding Frenzy of a Morphing 'Cell from Hell'. The Washington Post, 9 jun. 1997. Disponível em: https:/www.washingtonpost.com/archive/politics/1997/06/09/the-feeding-frenzy-of-amorphing-cell-from-hell/d3fd61b4-25c5-44ca-8520-fff7f5b2c7a1/. Acesso em: 23 jul. 2020.

WEIL, Kari. Killing Them Softly: animal death, linguistic disability, and the struggle for ethics. Configurations, v. 14, n. 1, p. 87-96, 2008.

WOLFE, Cary. In the Shadow of Wittgenstein's Lion: Language, Ethics. In: WOLFE, Cary. Zoontologies: The Question of the Animal. University of Minnesota Press, Minneapolis, 2003. p. 1-58.

YOON, Carol Kaesuk. Oozing through Texas Soil, a Team of Amoebas Billions Strong. The New York Times. Nova York, 23 mar. 2009. Disponível em: https://www.nytimes.com/2009/03/24/science/24amoe.html\#: :text=Scientists $\% 20$ foun $\mathrm{d} \% 20$ the $\% 20$ vast $\% 20$ and, unexpected $\% 2 \mathrm{C} \% \mathrm{E} 2 \% 80 \% 9 \mathrm{D} \% 20$ said $\% 20$ Owen $\% 20 \mathrm{M}$.

Acesso em: 23 jul. 2020. 


\begin{abstract}
In this article, Karen Barad entertains the possibility of the queerness of one of the most pervasive of all critters - atoms. These "ultra-queer" critters with their quantum quotidian qualities queer queerness itself in their radically deconstructive ways of being. Given that queer is a radical questioning of identity and binaries, including the nature/culture binary, this article aims to show that all sorts of seeming impossibilities are indeed possible, including the queerness of causality, matter, space, and time. What if queerness were understood to reside not in the breech of nature/culture, per se, but in the very nature of spacetimemattering, Barad asks. This article also considers questions of ethics and justice, and in particular, examines the ways in which moralism insists on having its way with the nature/culture divide. Barad argues that moralism, feeds off of human exceptionalism, and, in particular, human superiority and causes injury to humans and non-humans alike, is a genetic carrier of genocidal hatred, and undermines ecologies of diversity necessary for flourishing.
\end{abstract}

Keywords: performativity; nature; entanglements.

Recebido em: 20/02/2021

Aceito em: 22/02/2021 